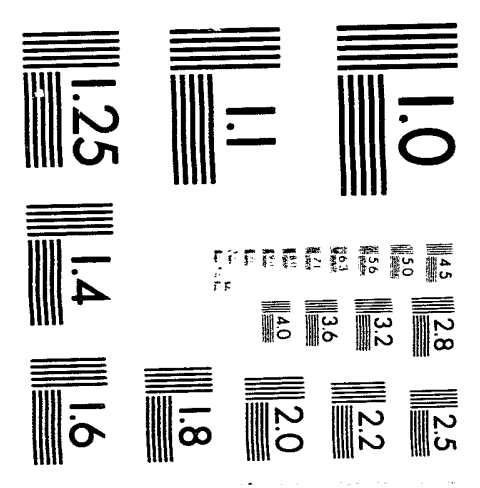



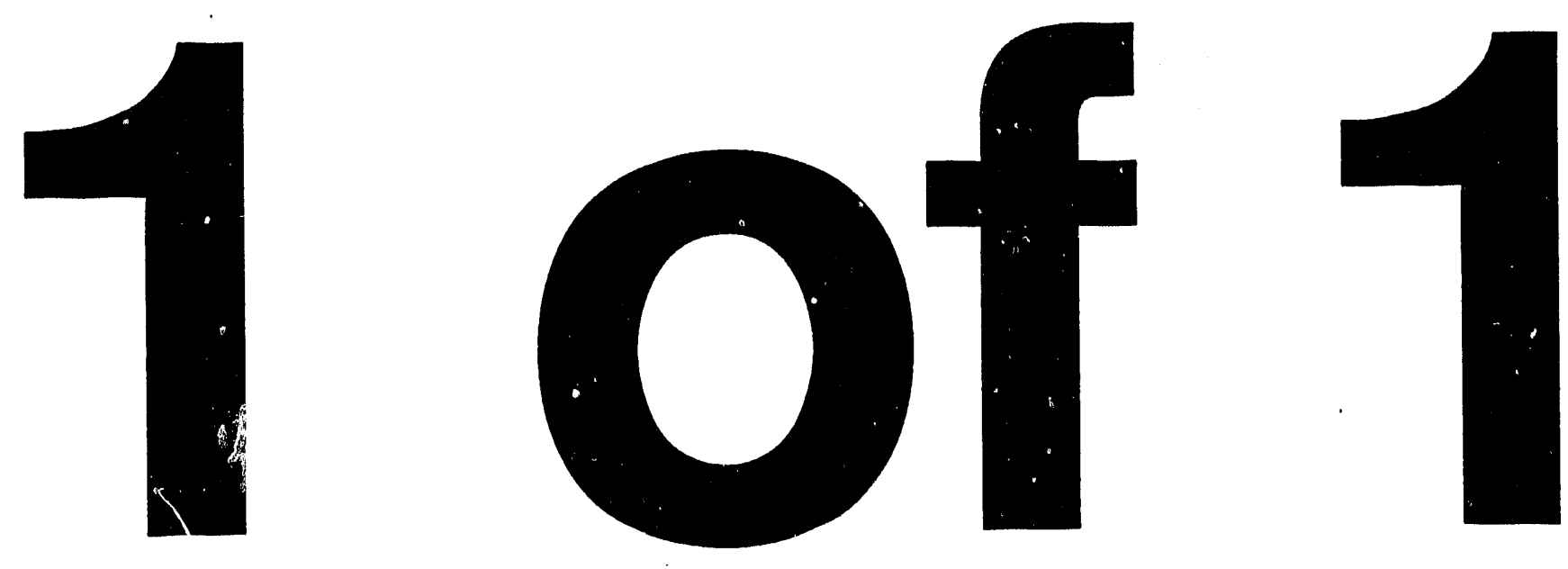


\section{0-BP-5 Operable Unit Technical Baseline Report}

I. D. Jacques

S. K. Kent

Date Published

October 1991

Prepared for the U.S. Department of Energy

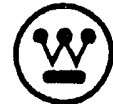




\section{LEGAL DISCLAIMER}

This report was prepared as an account of work sponsored by an agency of the United States Government. Neither the

United States Government nor any agency thereof, nor any of their employees, nor any of their contractors, subcontractors or their employe日s, makes any warranty, express or implied, or assumes any legal liability or responsibility for the accuracy, completeness, or any third party's use or the results of such use of any information, apparatus, product, or process disclosed, or represents that its use would not infringe privately owned rights. Reference herein to any specific commercial product, process, or service by trade name, trademark, manufacturer, or otherwise, does not necessarily constitute or imply its endorsement, recommendation, or favoring by the United States Government or any agency thereof or its contractors or subcontractors. The views and opinions of authors expressed herein do not necessarily state or reflect those of the United States Government or any agency thereof.

This report has been reproduced from the best available copy.

Pinted in the United States of America

DISCLM-2.CHP $(1 \cdot-91)$ 


\section{CONTENTS}

1.0 INTRODUCTION . . . . . . . . . . . . . . . . . . . . . . 1

2.0 OPERATIONS AT B PLANT AND ASSOCIATED FACILITIES . . . . . . . . . . . 1

2.1 ORIGINAL OPERATIONS AT B PLANT . . . . . . . . . . . . . . . . 1

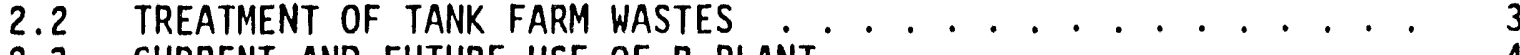

2.3 CURRENT AND FUTURE USE OF B PLANT . . . . . . . . . . . . . . 4

$3.0200-B P-5$ WASTE SITES AND UNPLANNED RELEASES . . . . . . . . . . . . 4

3.1 216-B-5 REVERSE WELL . . . . . . . . . . . . . . . . . . . 4

3.2 241-B-361 SETTLING TANK . . . . . . . . . . . . . . . . . . 9

3.3 216-B-9TF CRIB . . . . . . . . . . . . . . . . . . . . . . . 10

3.4 216-B-56 CRIB . . . . . . . . . . . . . . . . . . . . . . . 11

3.5 216-B-59 RETENTION BASIN . . . . . . . . . . . . . . . . . 12

3.6 241-B-154 DIVERSION BOX .................... 12

3.7 241-B-302 CATCH TANK ................... . 13

3.8 UNPLANNED RELEASE UN-200-E-7.................. 13

3.9 UNF'LANNED RELEASE UN-200-E-45 . . . . . . . . . . . . . . . . 14

3.10 UNPLANNED RELEASE UN-200-E-77 . . . . . . . . . . . . . . . . 14

4.0 REFERENCES... . . . . . . . . . . . . . . . . . . . . . 14

\section{APPENDICES}

A PHOTOGRAPHS . . . . . . . . . . . . . . . . . . . . . . . . A-1

B WASTE SITE SUMMARIES FROM THE WASTE

INFORMATION DATABASE SYSTEM ..................... B-1

\section{FIGURES}

3-1 B Plant and Waste Sites in the 200-BP-5 Operable Unit . . . . . . 5

3-2 Operating Summarj of B Plant and 200-BP-5 Waste Sites . . . . . . 6

3-3 Artist's Concept of 216-B-5 Reverse Well and 241-B-361 Settling

Tank. . . . . . . . . . . . . . . . . . . . . 8 


\subsection{INTRODUCTION}

This report supports development of a remedial investigation/feasibility study work plan for the 200-BP-5 operable unit. The report summarizes baseline information for waste sites and unplanned release sites located in the 200-BP-5 operabie unit. The sites were investigated by the Technical Baseline Section of the Environmental Engineering Group, Westinghouse Hanford Company (Westinghouse Hanford). The investigation consisted of review and evaluation of current and historical Hanford Site reports, drawings, and photographs, and was supplemented with recent inspections of the Hanford Site and employee interviews. No field investigations or sampling were conducted.

The 200-BP-5 operable urit consists of 1iquid-waste disposal sites and unplanned release sites located near, and related to, the 221-B Process Canyon Building (B Plant) and associated facilities. Each site in the operable unit is described separately. To understand the types of wastes discharged to the waste sites, a brief operating history of B Plant and the associated

facilities is provided. In addition, estimated waste inventories and current conditions are discussed for each waste site.

Appendix A contains photographs of the waste sites and the general operating area including B Plant. Appendix B contains a summary report for each waste site and unplanned release site compiled from the Waste Information Data System (WIDS) (WHC 1990). An environmental summary of the 200-BP-5 operable unit is not included in this report. A summary may be found in Inactive Waste Sites at Hanford (Stenner et a1. 1988), which describes geology and soils, meteorology, hydrology, land use, population, and air quality.

Resource centers used to gather information for this report included the Environmental Resource Center, the WIDS and Reference Library, the Hanford Site Drawing Station located at the Tri-Cities Professional Center, and the Boeing Computer Services Richland Photography Files located at $1100 \mathrm{Jadwin}$ Avenue, Richland, Washington. In addition, Westinghouse Hanford personnel contacted for specific information on the waste sites include personnel froni B Plant, B Tank. Farms, and 200 Area Environmental Protection.

Most of the historical documents used for this report give dimensions and values in English units of measure, and should be considered the most accurate. Those values taken from historical records are in bold.

\subsection{OPERATIONS AT B PLANT AND ASSOCIATED FACILITIES}

\subsection{ORIGINAL OPERATIONS AT B PLANT}

B Plant was constructed between August 1943 and February 1945 and operated from April 1945 to October 1952 using the bismuth phosphate process to separate plutonium from irradiated uranium fuel (Peterson 1990). The bismuth phosphate separations process was not as efficient as separations processes used later at Hanford and produced several types of radioactive and 
chemical wastes. Mixed fission and activation products, uranium, and transuranic elements such as plutonium were contained in wastes from the bismuth phosphate process. Wastes were segregated according to potential radionuclide contamination and stored or disposed of accordingly. High level wastes were stored in single-shell underground storage tanks while intermediate level wastes were routed to holding tanks and then to underground cribs or reverse wells for disposal. Low level wastes such as cooling water were routed to ponds and ditches for disposal (Smith 1980).

At B Plant, irradiated uranium fuel elements were first treated with boiling sodium hydroxide to dissolve and remove the aluminum jacket that encased each fuel element. Sodium nitrate was slowly added to the mixture to reduce the formation of hydrogen gas. In addition, some of the silicon used as a binder in the fuel elements was dissolved during jacket removal. The 'coating removal wastes' produced contained high levels of activation products as well as sodium silicate, sodium aluminate, and sodium nitrite (Stenner et a1. 1988). These wastes were routed to single-shell tanks at the $B$ Tank Farms (and beginning in 1946, the C Tank Farms) for storage.

The decladded fuel elements were then dissolved in nitric acid. Sulfuric acid was added to complex the uranium to prevent it from precipitating as uranyl phosphate during the later steps of the process. This metal solution was then pretreated with sodium nitrite to reduce the plutonium to the correct valence state for precipitation (Stenner et al. 1988). Next, bismuth nitrate and phosphoric acid were added to the solution. Bismuth phosphate was produced, which precipitated and complexed the plutonium. The resulting slurry was centrifuged. The acidic liquid waste was neutralized with sodium hydroxide and routed to the single-shell tanks for storage. This high level waste, called 'metal waste', contained the majority of the uranium from the fuel elements and about $90 \%$ of the original inventory of fission products as well as sodium nitrate, sodium sulphate, and other chemical wastes (DOE/RL 1991).

The precipitated 'cake' was then dissolved in nitric acid. Sodium dichromate or potassium permanganate was added to the solution to oxidize the plutonium. This step caused bismuth phosphate to precipitate while the oxidized plutonium remained in solution. The precipitated wastes from this 'first-cycle decontamination' were removed and routed to the single-shell tanks for storage. These high level wastes contained about $10 \%$ of the original fission product inventory, about $1 \%$ of the plutonium inventory, bismuth phosphate, and other chemical wastes (DOE/RL 1991).

The decontamination step was then repeated on the remaining 1 iquid. Bismuth nitrate and phosphoric acid were added to the solution. The bismuthnhosphate-plutonium precipitate was dissolved in nitric acid. Again, sodium ichromate or potassium permanganate were added to oxidize the plutonium causing bismuth phosphate to precipitate from the solution. The wastes produced from this second cycle precipitation, called 'second-cycle decontamination' wastes, contained $<0.1 \%$ of the fission product inventory, about $1 \%$ of the plutonium, and a mixture of chemical wastes similar to the first-cycle wastes (DOE/RL 1991). Originally, second cycle wastes were routed to single-shell tanks for storage. 
The plutonium solution was then routed to the 224-B Bulk Reduction

Building for further processing. At the 224-B building, sodium bismuthate was added to $1,249 \mathrm{~L}(330 \mathrm{gal})$ of the plutonium solution to oxidize the plutonium. Phosphoric acid was then added to precipitate bismuth phosphate with the plutonium remaining in solution. The solution was centrifuged to remove the liquid from the byproduct cake. The cake was dissolved in nitric acid, neutralized, and disposed of as waste.

Next, hydrofluoric acid and lanthanum salts were added to the plutonium solution. This was called the 'crossover step' and produced lanthanum fluoride, which carried the plutonium with it. Impurities were precipitated from the solution producing another bismuth phosphate cake. The cake was dissolved in nitric acid, neutralized, and disposed of as waste. Next, potassium hydroxide was added to the solution forming a plutonium lanthanum oxide precipitate. This mixture was then centrifuged and the precipitate was dissolved in nitric acid, forming plutonium nitrate. This solution, now about $30 \mathrm{~L}$ ( $8 \mathrm{gal}$ ), was sent to the $231-\mathrm{Z}$ Concentration Building for further processing. All waste solutions from the 224-B building were routed to settling tanks and then disposed of to the soil in either cribs or reverse wells.

At the 231-Z Isolation Facility, ammonium sulphate was added to the concentrated plutonium nitrate solution to reduce the plutonium, which was then precipitated by adding hydrogen peroxide. The plutonium peroxide precipitate was collected and dissolved in nitric acid to produce the final product, plutonium nitrate, which was placed in small shipping containers, boiled using hot air, and shipped to Los Alamos, New Mexico, for use.

\subsection{TREATMENT OF TANK FARM WASTES}

The 241-B, 241-BX, and 241-BY Tank Farms include 40 single-she11, underground storage tanks of sizes ranging from $204,412 \mathrm{~L}(54,000 \mathrm{gal})$ to $2,006,262 \mathrm{~L}(530,000 \mathrm{gal})$ each. Originally, coating removal waste, metal waste, first-cycle decontamination waste, and second-cycle decontamination waste were stored in the tanks (Cramer 1987). Stainless steel multipleencased 1 ines, $7.5 \mathrm{~cm}$ ( $3 \mathrm{in.}$ ) in diameter, routed wastes to underground concrete diversion boxes. From the diversion boxes, wastes were routed through multiple-encased 1 ines to specified storage tanks.

As tank space became scarce, second-cycle decontamination waste was settled in tanks and discharged to the soil through cribs or reverse wells. old second-cycle wastes were removed from the single-shell tanks, settled, and discharged to cribs or reverse wel1s. Later, in 1951, B Plant cell drainage wastes were combined with second-cycle wastes and wastes from the 224-B building. These combined wastes were settled in tanks and discharged to cribs and reverse wells.

The 242-B Evaporator began operation in December 1951. Unti1 it was shut down in October 1954, the 242-B Evaporator was used to process about $27,148,888 \mathrm{~L}(7,172,000 \mathrm{gal})$ of B Plant wastes. First cycle decontamination wastes were evaporated to concentrate the remaining wastes for further 
treatment and storage (DOE/RL 1991). Condensate and supernatants from the evaporator were routed to several soil disposal facilities in the B Plant area.

\subsection{CURRENT AND FUTURE USE OF B PLANT}

B Plant was shut down in 1952 after the Reduction-oxidation Plant began operation although some minor separations processing was conducted in $B$ Plant from 1963 through 1966. Beginning in 1968, B Plant was used to remove and recover cesium and strontium from the Plutonium Uranium Extraction Plant current acid waste and from high level supernatant liquids, as well as sludge from self-boiling liquid waste (Peterson 1990). In 1973, the Waste Encapsulation and Storage Facility (WESF) was added to the west end of B Plant. Here strontium, in the form of strontium fluoride, and cesium, in the form of cesium chloride, are encapsulated in stainless steel cylinders. The cylinders are stored in water-filled storage basins at the WESF (Stenner et a1. 1988).

Filtered Columbia River water is used for single-pass cooling through B Plant cooling coils, condensers, and heat exchangers. The combined flow of these cooling water discharges is about $6,435 \mathrm{~L}(1,700 \mathrm{gal})$ per minute. This waste cooling water is a nonradioactive, nonhazardous waste stream and is monitored and discharged to the 216-B-3 Pond (Peterson 1990).

The future mission of $B$ Plant has not been determined. A proposed mission for B Plant is to separate selected tank farm wastes into high level, transuranic, and low level portions. Separation will be the first process before final storage or disposal of these wastes (Peterson 1990). This proposed mission is under review by the U.S. Department of Energy, the U.S. Environmental Protection Agency, and the State of Washington Department of Ecology.

\subsection{0-BP-5 WASTE SITES AND UNPLANNED RELEASES}

Because of early operating practices and the lower efficiency of the bismuth phosphate process, liquid wastes discharged to 216-B sites potentially contain large amounts of contaminants.

The following sections describe each waste site and unplanned release site located in the 200-BP-5 operable unit. The operating history, types of wastes received, and a brief description is provided for each waste site. Figure 3-1 shows B Plant, the main process lines, and the waste sites in the 200-BP-5 operable unit. Figure 3-2 summarizes waste site operations.

\subsection{6-B-5 REVERSE WELL}

The 216-B-5 Reverse Well was one of the first liquid waste disposal facilities used on the Hanford Site. The well was designed and constructed to dispose of intermediate level liquid wastes from the B Plant. The well is 
Figure 3-1. B Plant and Waste Sites in the 200-BP-5 Operable Unit.

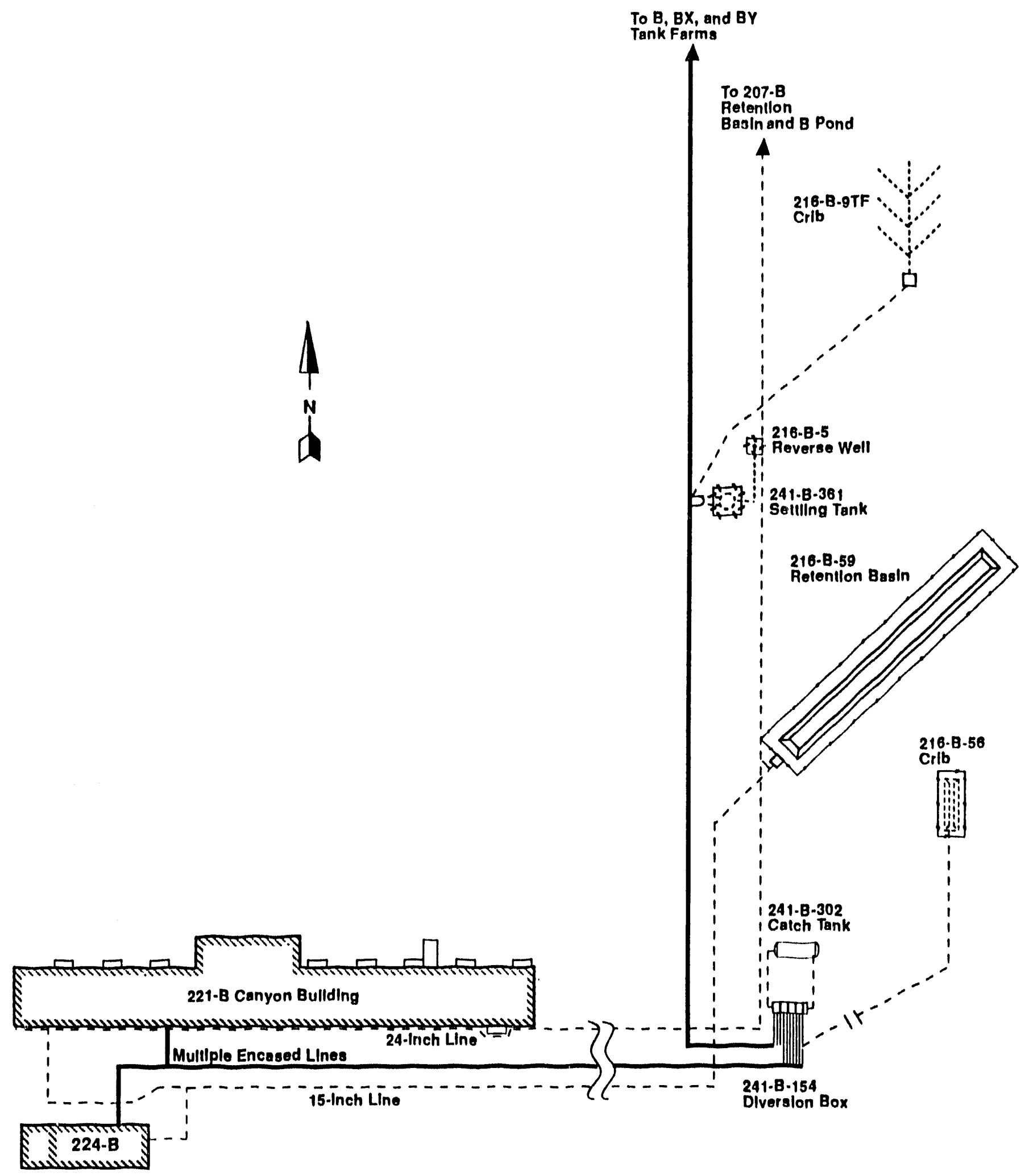

$39104079.1 \mathrm{FH}$ 


\section{To Present}

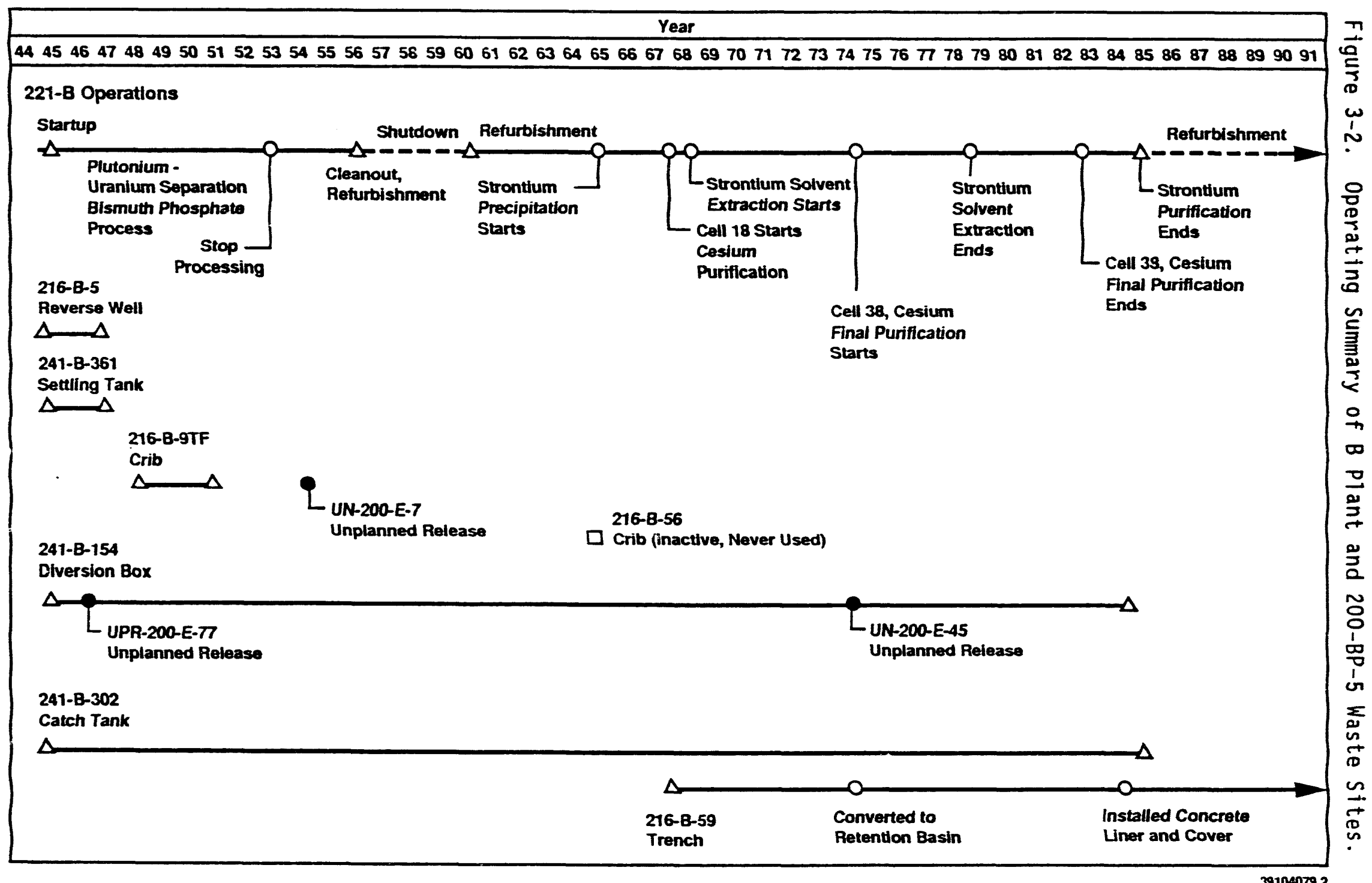


located about $305 \mathrm{~m}(1,000 \mathrm{ft})$ northeast of the B Plant in the 200 East Area at the approximate Hanford coordinates $\mathrm{N}-43480, \mathrm{~W}-52855$.

The we11 was completed to a depth of $92 \mathrm{~m}(302 \mathrm{ft})$ below ground in october 1944, using a telescoping casing technique. The well casing is $41 \mathrm{~cm}$ (16 in.) in diameter to a depth of $4 \mathrm{~m}(13 \mathrm{ft}), 31 \mathrm{~cm}$ (12 in.) in diameter casing to a depth of $31 \mathrm{~m}(100.5 \mathrm{ft}), 25 \mathrm{~cm}$ (10 in.) in diameter casing to a depth of $74 \mathrm{~m}(242 \mathrm{ft})$, and $20 \mathrm{~cm}(8 \mathrm{in}$.$) in diameter casing to a depth of$ $92 \mathrm{~m}(302 \mathrm{ft})$. The $20 \mathrm{-cm}(8 \mathrm{-in}$.) diameter casing section was perforated from a depth of $74 \mathrm{~m}(243 \mathrm{ft})$ to the bottom of the well to distribute the waste solutions to the surrounding sediments. A diagram of the well is shown on Figure 3-3. Drilling logs indicate that the water table in this area was about $89 \mathrm{~m}(292 \mathrm{ft})$ below the surface of the ground when the well was installed. This means the well penetrated the ground water by about $3 \mathrm{~m}$ (10 ft) (Smith 1980).

Waste entered the reverse well through a $5-\mathrm{cm}(2-$ in.) diameter stainless steel inlet pipe located about $3.66 \mathrm{~m}(12 \mathrm{ft})$ below the ground surface. An 8-cm (3-in.) diameter pipe, called a gageline, extended from ground level to within $15 \mathrm{~m}(50 \mathrm{ft})$ of the bottom of the well. This system was used to determine liquid level in the well and warn operators if the well was filling with liquid waste (Smith 1980).

The well was put into operation on April 1, 1945, with the associated 241-B-361 Settling Tank. The system received cell drainage waste (contaminated waste water) from the Tank 5-6 located in the 221-B Process Canyon Building and low-salt, neutralized (alkaline) 1 lquid wastes from the 224-B facility. The wastes first entered the 241-B-361 Settling Tank where the solid materials were allowed to settle. The supernatant liquids then overflowed to the 216-B-5 Reverse Well for disposal (Stenner et al. 1988). From September 1946 to October 1947, the system received only cell drainage waste from the Tank 5-6 in the 221-B Process Canyon Bullding. During that time, 1 iquid wastes from the $224-B$ building were rerouted to the new 216-B-7A Crib (Lundgren 1970).

The 216-B-5 Reverse Well was taken out of service on September 19, 1947 when a water sample from well $299-E 33-18$, 10cated $610 \mathrm{~m}(2,000 \mathrm{ft})$ to the north, indicated alpha contamination in the ground water. Two days 1 ater, the wastes normally routed to the 216-B-5 Reverse Well were rerouted to the 216-B-7A and 216-B-7B cribs. At a later date, the inlet pipe to the well was blanked off to prevent further use of the waste site. During operation of the 216-B-5 Reverse Well and 241-B-361 Settling Tank, approximately 30,600,000 L $(8,083,689.9 \mathrm{gal})$ of liquid wastes were discharged to the waste site. In addition, studies indicate that as much as $2 \mathrm{~kg}(4.41 \mathrm{lb})$ of plutonfum were discharged to the sediments surrounding the well during its operation (Smith 1980). Appendix B contains a summary of radionuclides and chemicals discharged to the waste site.

In 1979, three wells were drilled near the 216-B-5 Reverse Well to document the distribution of radionuclides (Sinith 1980). In addition, one existing well was deepened. Analys is of sediment samples collected beneath this waste site indicate the sediments are contaminated with a significant amount of plutonium as well as strontium-90 and cesium-137 (Smith 1980). 
Figure 3-3. Artist's Concept of 216-B-5 Reverse We11 and 241-P,-361 Settling Tank.

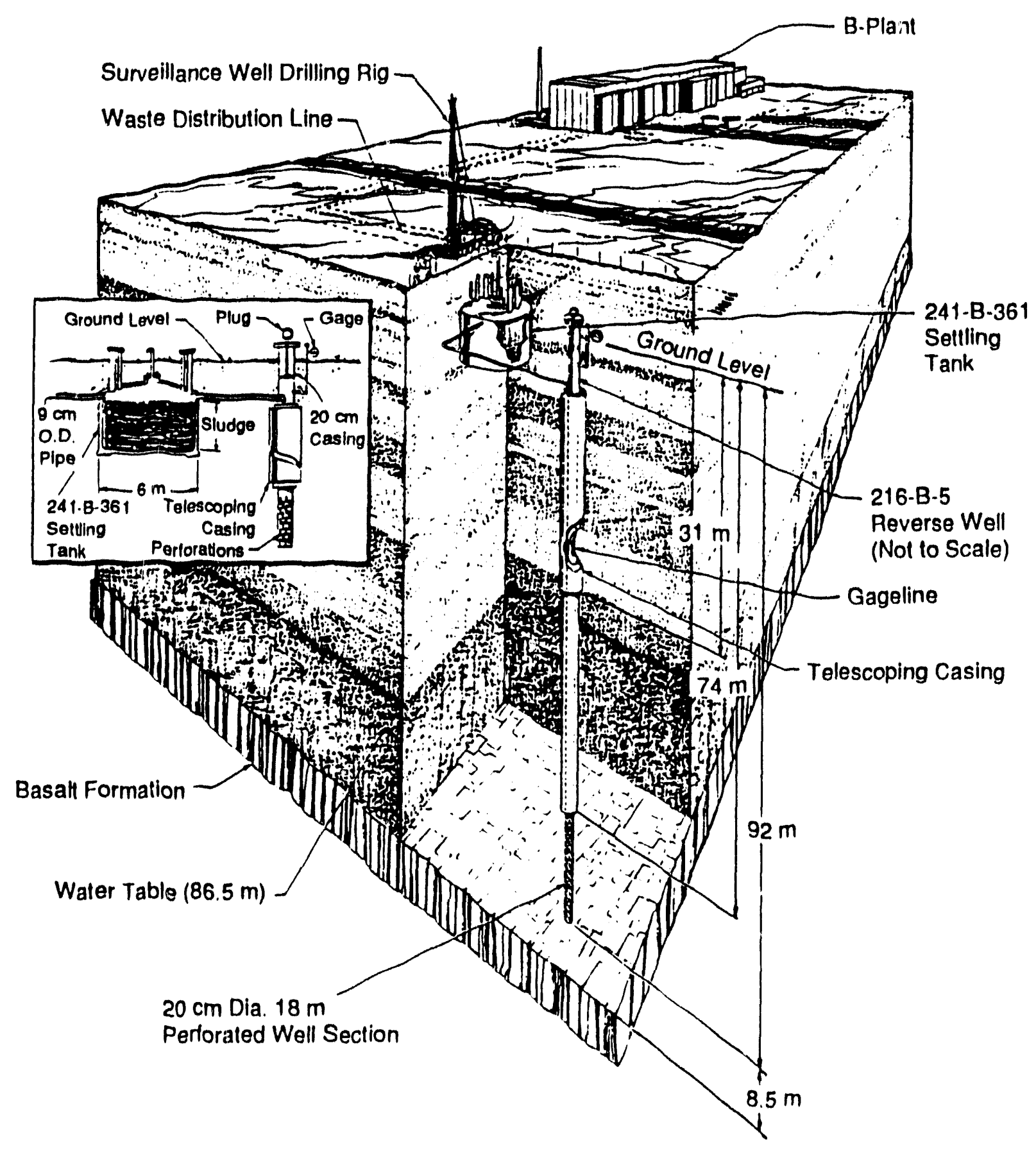


Recent ground water samples from these wells continue to indicate elevated concentrations of strontium-90, cesium-137, and plutonium in the unconfined aquifer near the 216-B-5 Reverse We11. In 1988, the average concentration of strontium-90 near the 216-B-5 Reverse Weli ranged from 68 to $5,238 \mathrm{pCi} / \mathrm{L}$. The average concentration of cesium-137 ranged from 2 to $1,480 \mathrm{pCi} / \mathrm{L}$. Plutonium concentration values near the reverse well were not reported, but were stated to be above control values (Serkowski and Jordan 1988).

Current1y, the well is controlled as a surface radioactive contamination zone and is surrounded with a chain barrier to prevent unauthorized entry into the waste site.

\subsection{1-B-361 SETTLING TANK}

As described in the previous section, the 241-B-361 Settling Tank was used in conjunction with the 216-B-5 Reverse We11. The tank is an underground tarik, located in the 200 East Area at the approximate Hanford coordinates N-43300, W-52900 (Crusselle 1982).

The 241-B-361 Settling Tank is $6 \mathrm{~m}(20 \mathrm{ft})$ in diameter and $6 \mathrm{~m}(19 \mathrm{ft})$ in height. It is constructed of $15-\mathrm{cm}\left(6-i n_{.}\right)$reinforced, prestressed concrete, with the top of the tank 10cated $2 \mathrm{~m}$ ( $6 \mathrm{ft}$ ) below grade (Cramer 1987). Eleven risers are visible above grade. One riser is equipped with a manual level

tape, a second riser contains two dip tubes, and a third riser vents the tank. The eight remaining risers are blanked off.

The tank, constructed during late 1944 and early 1945, was put into operation on April 1, 1945. Cell drainage wastes from Tank 5-6 at B Plant and low-salt, neutralized (alkaline) wastes from the 224-B building were routed through a $7.5 \mathrm{-cm}(3-\mathrm{in.})$ diameter stainless steel inlet pipe to the tank. The liquids were allowed to accumulate to a level of $5 \mathrm{~m}(15 \mathrm{ft}$ ) before spilling into the $5-\mathrm{cm}(2-\mathrm{in}$.$) diameter stainless steel outlet pipe leading to the$ 216-B-5 Reverse We11. A baffle in front of the outlet pipe prevented the wastes from directly exiting the tank before the solid materials could settle out.

From September 1946 to October 1947, the system received only cell drainage waste from Tank 5-6 in the 221-B Process Canyon Building. During that time, liquid wastes from the 224-B building were rerouted to the new 216-B-7A Crib. As stated in the previous section, this disposal system was taken out of service on September 19, 1947. It was determined that sediments surrounding the 216-B-5 Reverse We11 had become saturated with radionuclides and were contaminating the nearby ground water.

In 1979, two shallow wells were drilled to the north and south of the 241-B-361 Settling Tank. The we11s are $12 \mathrm{~m}$ (40 ft) deep (Smith 1980). Sediments from the boreholes were tested and determined to be free of radioactive contaminants, indicating that the tank had not leaked. In addition, two sludge samples were collected from the tank. Tests showed that the solid materials in the tank are primarily bismuth phosphate contaminated with mixed fission products and about $2.4 \mathrm{~kg}(5.29 \mathrm{lb})$ of plutonium. In addition, tests on the sludge show it contains a relatively high proportion of 
WHC-MR-0270

strontium-90 as compared to cesium-137, an associated long- 1 ived fission product. These data indicate that the strontium-90 tended to complex with the bismuth salts while the more soluble cesium-137 remained in solution and was discharged to the 216-B-5 Reverse Well (Smith 1980). Appendix B contains a summary of radionuclides and chemicals discharged to the waste site.

The inlet pipe to the tank has been blanked off. There are no pumpable liquids in the tank. The volume of the sludge is about $120,000 \mathrm{~L}$ $(31,700 \mathrm{gal})$. Currently the tank area is controlled as a surface radioactive contamination zone and is surrounded with a chain barrier to prevent unauthorized entry.

\subsection{6-B-9TF CRIB}

The 216-B-9TF Crib was constructed in early 1948 and began operation in August 1948. The waste site is located approximately $381 \mathrm{~m}(1,250 \mathrm{ft})$ south of the 241-B Tank Farm, at Hanford coordinates N-43757, W-52617 to N-43944, W-52617 (Maxfield 1979).

The crib structure is an open-bottomed wooden box, constructed of $15.24-\mathrm{cm}(6-\mathrm{in}$.$) by 15.24-\mathrm{cm}(6-\mathrm{in.})$ creosoted, pressure-treated timbers. The crib is $4.27 \mathrm{~m}$ (14 ft) long by $4.27 \mathrm{~m}(14 \mathrm{ft}$ ) wide by $2.13 \mathrm{~m}$ (7 ft) high with the top buried about 2.44 to $3.05 \mathrm{~m}(8$ to $10 \mathrm{ft})$ below the soil surface. The top of the crib structure was covered with roofing felt.

To activate the 216-B-9TF Crib, the inlet line to the 241-B-361 Settling Tank was cut, blanked, and rerouted to the 216-B-9TF Crib. This 8-cm (3-in.) diameter inlet pipe enters the wooden crib structure at the top, allowing solid materials in the wastes to settle. The crib has a 10-cm (4-in.) vent pipe extending above ground level with a particulate filter on the top of the vent pipe.

Supernatant liquids overflowed from the crib to the tile field through a 15-cm (6-in.) diameter vitrified clay outlet pipe positioned about $0.3 \mathrm{~m}$ $(1 \mathrm{ft})$ from the top of the wooden structure. The tile field consists of a 55-m (180-ft) length of double-strength, perforated clay pipe with three 18-m $(60-\mathrm{ft})$ lengths of clay pipe coming off of each side of the main pipe at 45-degree angles. The resulting tile field is in a 'herring-bone'

configuration. The clay pipes are buried $4 \mathrm{~m}(12 \mathrm{ft})$ deep at the front end and about $2 \mathrm{~m}(6 \mathrm{ft})$ deep at the back end in a sloped trench measuring $1.3 \mathrm{~m}$ $(4 \mathrm{ft}$ ) in width at the bottom. There are $46 \mathrm{~cm}(18 \mathrm{in.})$ of gravel above and below the pipes (Stenner et al. 1988). Test wells were installed between the legs of the tile field to monitor the extent of radionuclide release and absorption.

The 216-B-9TF Crib was used to dispose of low-salt, neutralized (alkaline) cell dralnage waste from the B Plant Tank 5-6. The Tank 5-6 was used to accumulate B Plant wastes for final disposal. Based on the operating history of B Plant, it is likely that during 1951, second-cycle wastes from $B$ Plant were also discharged to this site. These wastes would have been similar to wastes discharged to the 216-B-5 Reverse We11, containing 
plutonium, mixed fission products, bismuth phosphate, and other chemicals (Stenner et al. 1988). Appendix B contains a summary of radionuclides and chemicals discharged to the waste site.

The 216-B-9TF Crib was taken out of service in July 1951. The jumper in the 241-B-154 Diversion Box was removed and wastes were no longer discharged to the unit (Maxfield 1979).

The waste unit is controlled as a surface radioactive contamination zone and surrounded with a chain barrier to prevent unauthorized entry. Recently, several areas of radionuclide contamination have been detected on the surface of the waste site. These "hot spots" have been marked and are scheduled for cleanup. Although the soil surface does not show subsidence, workers in this area should be aware that the wooden crib structure could collapse under a load, potentially causing injury and spreading radioactive contamination.

\section{$3.4216-B-56$ CRIB}

The 216-B-56 Crib is an unused drain-field crib in the 200 East Area. The crib is located about $305 \mathrm{~m}(1,000 \mathrm{ft})$ northeast of B Plant at Hanford coordinates N-42885, W-52600 to N-.42955, W-52600 (Maxfield 1979).

According to the design drawings, the 216-B-56 Crib was built during late 1965 to early 1966. Since the crib was never activated, exact construction dates could not be confirmed. The crib excavation was about $31 \mathrm{~m}(100 \mathrm{ft})$ long by $12 \mathrm{~m}(40 \mathrm{ft})$ wide by $5 \mathrm{~m}(17 \mathrm{ft})$ deep. The bottom dimensions were $22 \mathrm{~m}$ (70 ft) long by $3 \mathrm{~m}(10 \mathrm{ft})$ wide. The crib had natural earthen sides with a $1: 2$ slope on the bottom $4 \mathrm{~m}(12 \mathrm{ft})$ and a $1: 11 / 2$ slope on the top $1.5 \mathrm{~m}$ (5 ft) (Maxfield 1979).

The 216-B-56 Crib contains a single $10-\mathrm{cm}$ (4-in.) perforated clay pipe with no lateral arms. The pipe is $22 \mathrm{~m}(70 \mathrm{ft})$ in length and rests on a $1.5-\mathrm{m}$ (4-foot) deep bed of gravel. A $0.015-\mathrm{cm}(0.006-$ in.) thick polyethylene barrier was placed on top of the gravel and overlapped the earthen sides by $0.6 \mathrm{~m}(2 \mathrm{ft})$. The membrane barrier was covered with sand. The crib pipe is buried about $4 \mathrm{~m}(13 \mathrm{ft})$ below grade.

An $8-\mathrm{cm}(3-$ in.) stainless steel inlet line extends from the crib to the vicinity of the 241-B-154 Diversion Box, but was never connected to the diversion box (Lundgren 1970). A vent pipe and two gage wells extend from the crib to about $1 \mathrm{~m}(3 \mathrm{ft})$ above grade.

The 216-B-56 Crib was designed to receive organic waste from the strontium and cesium recovery activities at B Plant, but was never activated. The inlet lines were never connected and the waste unit has never recelved waste (Maxfield 1979).

In the past, the sediments beneath this site have been cross-contaminated by other nearby sites. Clean fill has been placed on top of the site to stabilize it. This study was not able to determine when this site was stabilized. Currently, the waste site is controlled as an underground radioactive contamination zone and is surrounded with a chain barrier to prevent unauthorized entry. 
WHC-MR-0270

\subsection{6-B-59 RETENTION BASIN}

The 216-B-59 Retention Basin is an active liquid waste facllity located about $214 \mathrm{~m}(700 \mathrm{ft})$ northeast of B Plant at Hanford coordinates $\mathrm{N}-43001$, W-52787 to $\mathrm{N}-43284, \mathrm{~W}-52504$ (Maxfield 1979). The facility appears to have several aliases and has been referred to as the 216-B-58 Ditch, the 216-B-58 Trench, or the 216-B-59 Trench.

The 216-8-59 Retention Basin was originally designed and built in about 1967 to function as an open disposal basin for low-level liquid wastes. The basin was $122 \mathrm{~m}(400 \mathrm{ft})$ long and $6 \mathrm{~m}(20 \mathrm{ft})$ wide at the bottom. The basin was about $5 \mathrm{~m}(15 \mathrm{ft})$ deep with natural earthen sides with a $1: 2$ slope.

Potentially radioactive cooling water from B Plant tank cooling coils was routed through a $38-\mathrm{cm}(15-$ in.) 1 ine to a diverter station at the 216-B-59 Reterition Basin. Under normal conditions, this waste water was combined with cooling water in the $61-\mathrm{cm}$ (24-in.) i ine and discharged to the 216-B-3 Pond (B Pond) (Peterson 1990). If radionuclide levels in the 38-cm (15-in.) line exceeded predetermined levels, the waste water was diverted into the 216-B-59 Retention Basin. One such diversion occurred in March 1968. Appendix $B$ contains a summary of radionuclides discharged to the original 216-B-59 Trench.

From 1ate 1974 to early 1975, the 216-B-59 Retention Basin was modified and 1 ined on the bottom and sides with a nonpermeable plastic liner. The unit still received the same wastes, diverted cooling water from $B$ Plant, but was used as a retention basin. Waste water diverted to the 216-B-59 Retention Basin was pumped back to B Plant for reprocessing and then again routed to B Pond for disposal.

In November 1984, the plastic liner was removed and the bottom and sides were relined with a $12-\mathrm{cm}(4.5-\mathrm{in}$.) concrete slab. The concrete-lined bas in is divided into three sections and rovered with a prestressed concrete cover. Currently the waste unit is used for the same purpose, retention of potentially contaminated cooling water from B Plant. The waste unit is controlled as a surface radioactive contamination zone and is surrounded with a chain-link fence to prevent unauthorized entry.

\subsection{1-B-154 DIVERSION BOX}

The 241-B-154 Diversion Box is an inactive diversion box located in the 200 East Area directly east of B Plant at Hanford coordinates N-42543, W-52758 (Maxfield 1979). The 241-B 154 Diversion Box was used to transfer high level processing and decontamination wastes from B-P1ant, 201-C Semiworks, and the $B, B X$, and BY Tank Farms. Waste volumes varied according to specific plant operations.

The 241-B-154 Diversion Box was put in operation in 1945 and remained in service unti1 June 1984. The diversion box is constructed of $0.6-\mathrm{m}(2-\mathrm{ft})$ thick reinforced-concrete, and is $11 \mathrm{~m}$ (36 ft) long by $3 \mathrm{~m}(9 \mathrm{ft})$ wide by $5 \mathrm{~m}$ (17 ft) high (Cramer 1987). The unit is buried, with about $46 \mathrm{~cm}$ (18 in.) of the structure visible above ground. 
The 241.B-154 Diversion Box contains $248-\mathrm{cm}$ (3-in.) 'Hanford style' nozzles. Encased liquid-waste transfer lines enter the diversion box through its south wall. Liquid wastes are routed through the diversion box with jumper assemblies that connect pairs of waste transfer lines. Multipleencased 1iquid-waste transfer 1 ines extt the south wall of the diversion box and remain in place between the unit, processing plants, and single-shell storage tanks.

Besides transferring waste liquids, the diversion box is designed to contain leaks from transfers within the unit. Liquids accumulating in the diversion box drained to the attached 241-B-302 Catch Tank.

The pipelines to and from this 241-B-154 Diversion Box were sealed off when the unit was deactivated. The above-ground portion of the box was covered with polyurethane foam to protect it from the weather. Contamination within the diversion box is estimated to be high in alpha-, beta-, and gamma-emitting racionuclides. Some spotty radioactive contamination has been detected on the outside walls of the diversion box. The waste unit is controlled as a surface radioactive contamination zone and is surrounded with a chain barrier to prevent unauthorized entry.

\subsection{1-B-302 CATCH TANK}

The 241-B-302 Catch Tank is an underground storage tank associated with the 241-B-154 Diversion Box. The 241-B-302 Catch Tank is 1ocated in the 200 East Area directly east of B Plant at Hanford coordinates N-42600, W-52758 (DOE/RL 1991).

The 241-B-302 Catch Tank is an 11-m (36-ft) long by 3-m (9-ft) diameter stainless-steel tank. The capacity of the tank is $66,941 \mathrm{~L}(17,684 \mathrm{gal})$. The tank was put into operation in 1945 and was used to collect liquids spilled in the 241-B-154 Diversion Box. Rainwater seeping into the 216-B-154 Diversion Box would also drain into the catch tank. Liquids drained to the 241-B-302 Catch Tank would be periodicaliy pumped out and disposed to singleshel1 storage tanks (DOE/RL 1991). Liquids were last removed from the tank on May 10, 1985. At that time, 188,513 L (4,980 gal) of liquid (and probably some sludge) remained in the tank.

In July 1985, the 241-B-154 Diversion Box and the 241-B-302 Catch Tank were removed from service. The catch tank has been secured by capping off the inlet and outlet nozzles (DOE/RL 1991). The tank area has been stabilized; there are no vent lines or standpipes visible above grade (Hanlon 1990). The surface area above the catch tank is controlled as a surface radioactive contamination zone and is surrounded with a chain barrier to prevent unauthorized entry.

\subsection{UNPLANNED RELEASE UN-200-E-7}

On November 30,1954 , approximately $18,927 \mathrm{~L}(5,000$ gal) of cell waste water leaked from a waste line from the 221-B Process Canyon Bullding. The waste water contaminated a $9-m(30-f t)$ by $9-m(30-f t)$ section of soll located 
near the 216-B-9TF crib. Records indicate only that the maximum dose rate at the time of the spill was $1.7 \mathrm{rad} / \mathrm{h}$. There appears to be no record of the types and amounts of radionuclides spilled.

The pipeline leak was repaired and the contaminated soll was covered with clean fill. The area was posted for underground contamination. This study was not able to determine the exact location of this spill. It appears that the area has since been resurveyed and released.

\subsection{UNPLANNED RELEASE UN-200-E-45}

On August 26, 1954, a cleanup operation at the 241-B-154 Diversion Box inadvertently contaminated an area socitheast of the diversion box. The contamination covered a $183-\mathrm{m}(300-\mathrm{ft})$ by $30-\mathrm{m}(100-\mathrm{ft})$ area at Hanford coordinates N-42529, W-52725. The spill site included a portion of 7 th Street.

The sp 111 area contained radioactive contamination measuring up to 50,000 counts per minute beta/gamma. The exact source of the contamination is not known. The contaminated roadway was washed off with water and the roadway shoulder was bladed. The contaminated soil was collected and placed in a burial trench (Stenner et al. 1988).

\subsection{UNPLANNED RELEASE UN-200-E-77}

During 1946, $h$ !gh level waste from the 241-B-154 Diversion Box was spllled on the soll near the corner of 7 th Street and Baltimore Avenue at Hanford coordinates $\mathrm{N}-42550, \mathrm{~W}-52800$. Metal waste solution from B Plant, containing uranium and as much as $1 \mathrm{Ci}$ of mixed fission products, was spilled while a leaky jumper in the diversion box was being repaired or replaced (Stenner et al. 1988).

The exact date of the spill is not krown because the soll contamination was not discovered until October 1975. At that time, a radiological survey of the area detected contamination reading as high as 80,000 counts per minute. Clean fill (0.3 m [1 ft]) was placed on the spill area to stabilize the site. Recent radiological surveys have detected some recontamination of the spill site (Stennier et al. 1988).

\subsection{REFERENCES}

DOE/RL, 1991, Hanford Site Waste Management Units Report, DOE/RL-88-30, Rev. 1, prepared by Waste Management Technology, Westinghouse Hanford Company for U.S. Department of Energy, Richland Operations, Richland, Washington.

Hanlon, B. M., 1990, Tank Farm Surveillance and Waste Status Summary Report for July 1990, WHC-EP-0182-28, Westinghouse Hanford Company, Richland, Washington. 
Lundgren, L. L., 1970, 200 East and North Areas Radioactive Liquid Waste Disposal Sites, ARH-1562, Atlantic Richfield Hanford Company, Richland, Washington.

Maxfield, H. L., 1979, 200 Area Waste Sites, Volumes 1, 2, and 3, RHO-CD-673, Rockwel1 Hanford Operations, Richland, Washington.

Peterson, K. A., 1990, B Plant Cooling Water Stream-Specific Report, WHC-EP-0342, Addendum 22, Westinghouse Hanford Company, Rich1and, Washington.

Serkowski, J. A., and W. A. Jordan, 1988, Operational Groundwater Monitoring at the Hanford Site--1988, WHC-EP-0260, Westinghouse Hanford Company, Richland, Washington.

Smith, R. M., 1980, 216-B-5 Reverse Well Characterization Study, RHO-ST-37; Rockwell Hanford Operations, Richland, Washington.

Stenner, R. D., K. H. Cramer, and D. A. Lamar, 1988, Hazard Ranking System Evaluation of CERCLA Inactive Waste Sites at Hanford, Volumes 1, 2, and 3, PNL-6456, Battelle Northwest Laboratories, Richland, Washington.

WHC, 1990, WIDS Database Field Descriptions and Data, WHC-MR-0056, Rev. 0, Westinghouse Hanford Company, Richland, Washington. 
WHC-MR-0270

\section{APPENDIX A}

PHOTOGRAPHS 
WHC-MR-0270

\section{PHOTOGRAPHS}

A-1 B P1ant, March $1966 \ldots \ldots \ldots$. . . . . . . . . A-3

A-2 Inside the 221-B Process Canyon Butlding . . . . . . . . . A-4

A-3 B Plant and WESF, $1981 \ldots \ldots \ldots \ldots$. . . . . . . . . A

A-4 B Plant and WESF, $1987 \ldots \ldots \ldots$. . . . . . . . . A

A-5 216-B-5 Reverse We11 . . . . . . . . . . . . A-7

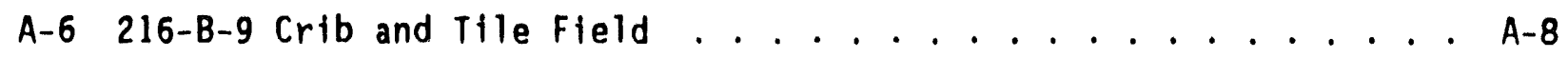


rigure A-1. B Plant, March 1966.

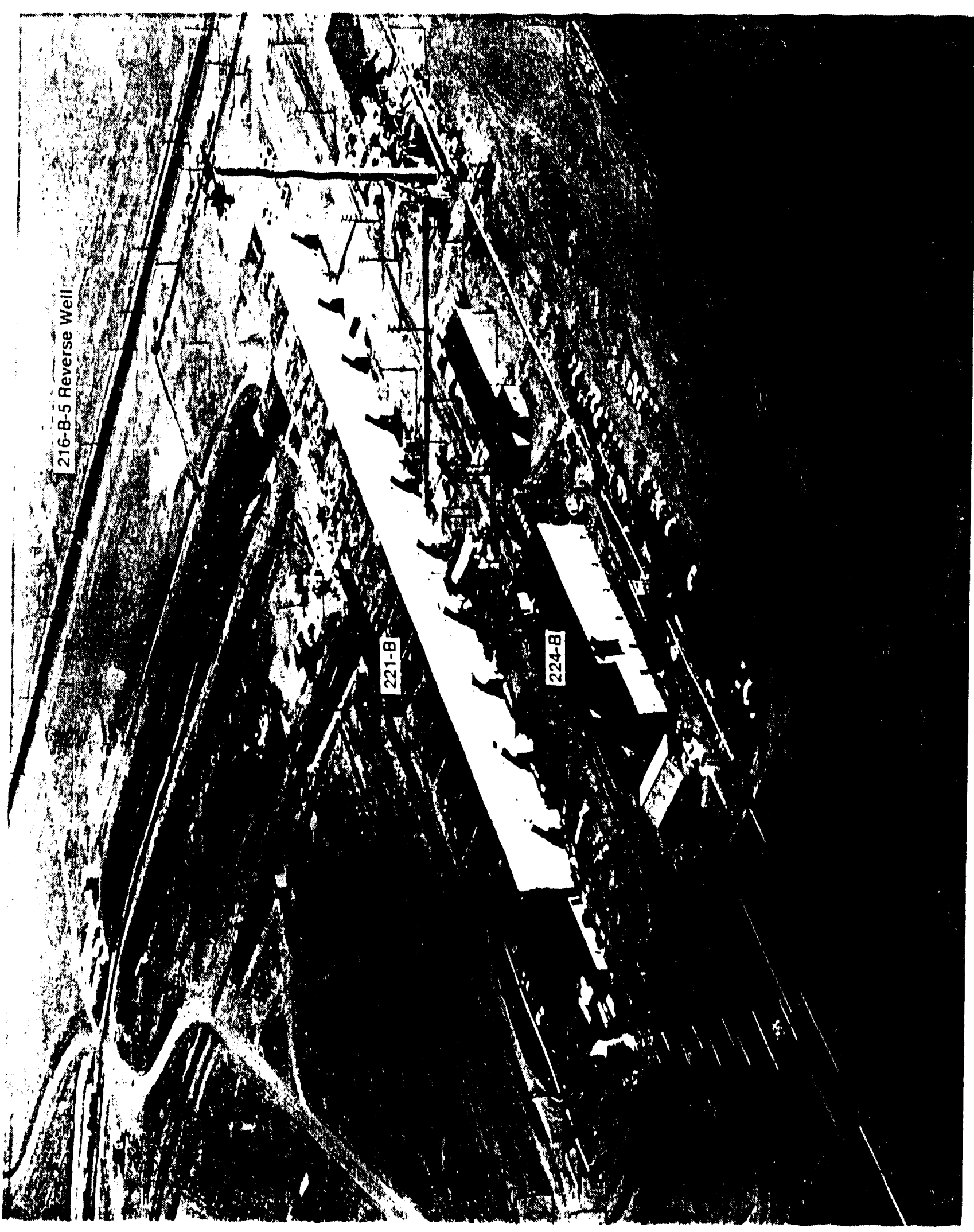




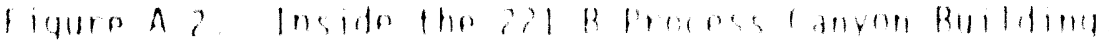

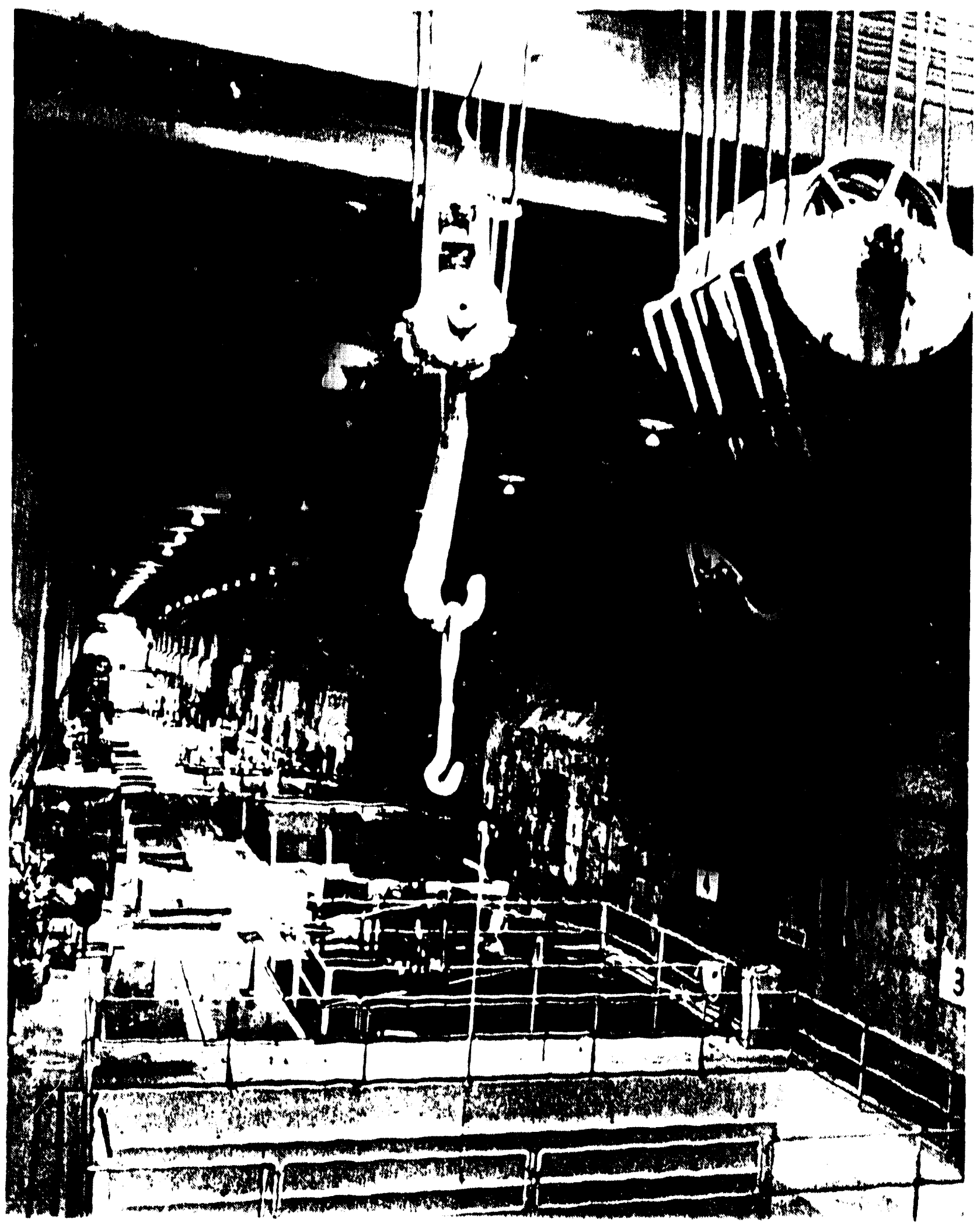




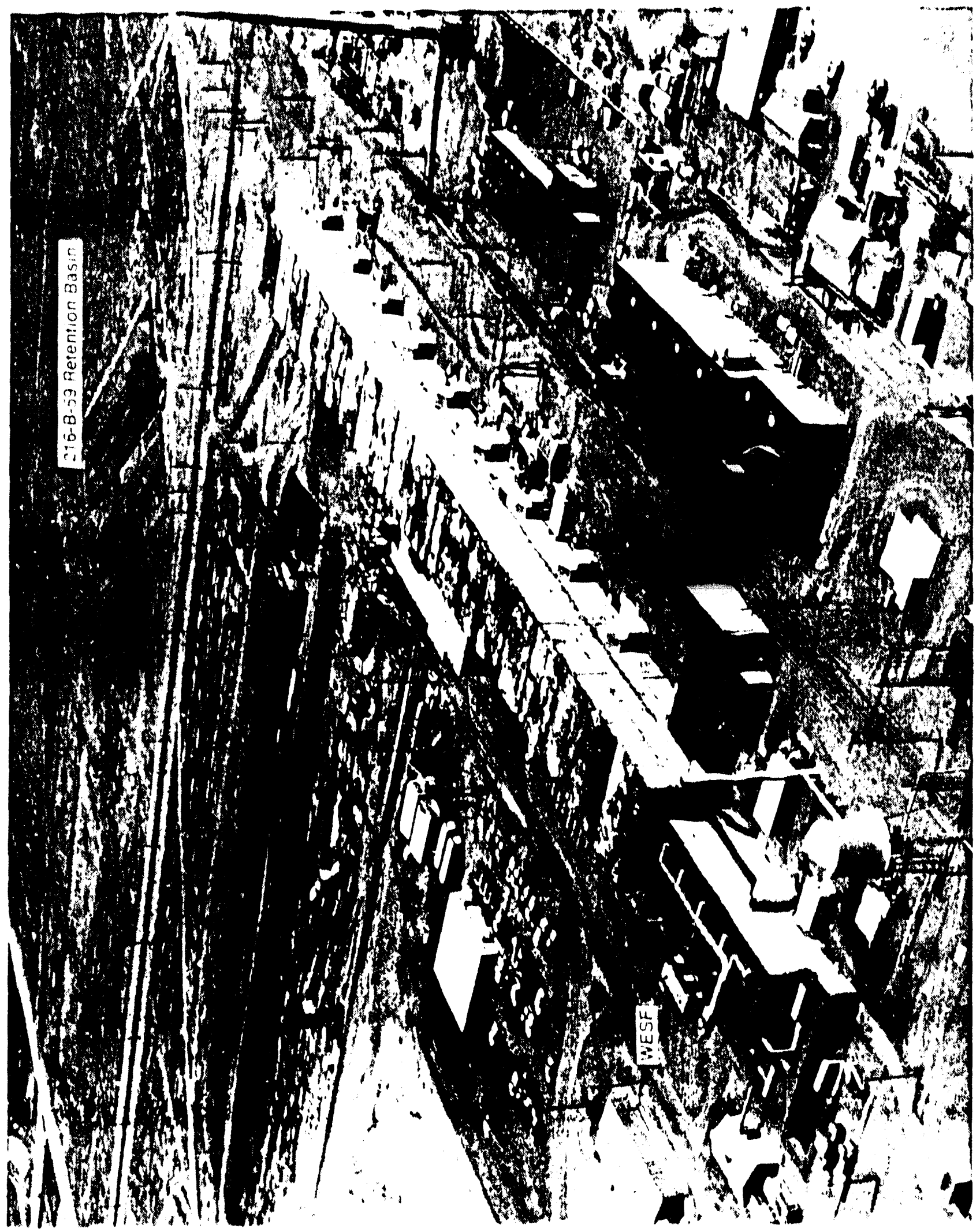


rigure A 4. B Plant and WF SF. 1987

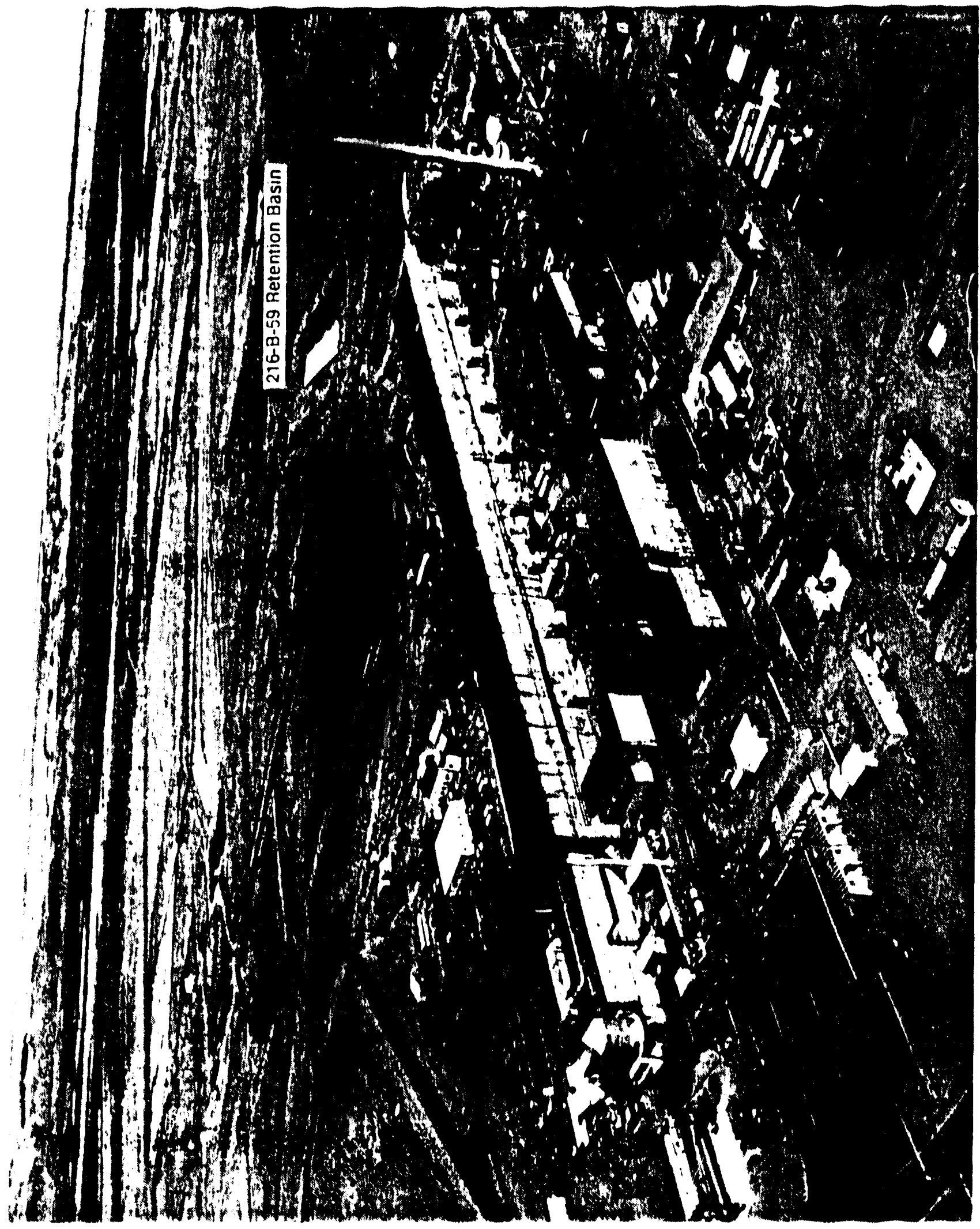


Figure A-5. 216-B-5 Reverse We11 (241-B-361 in background).

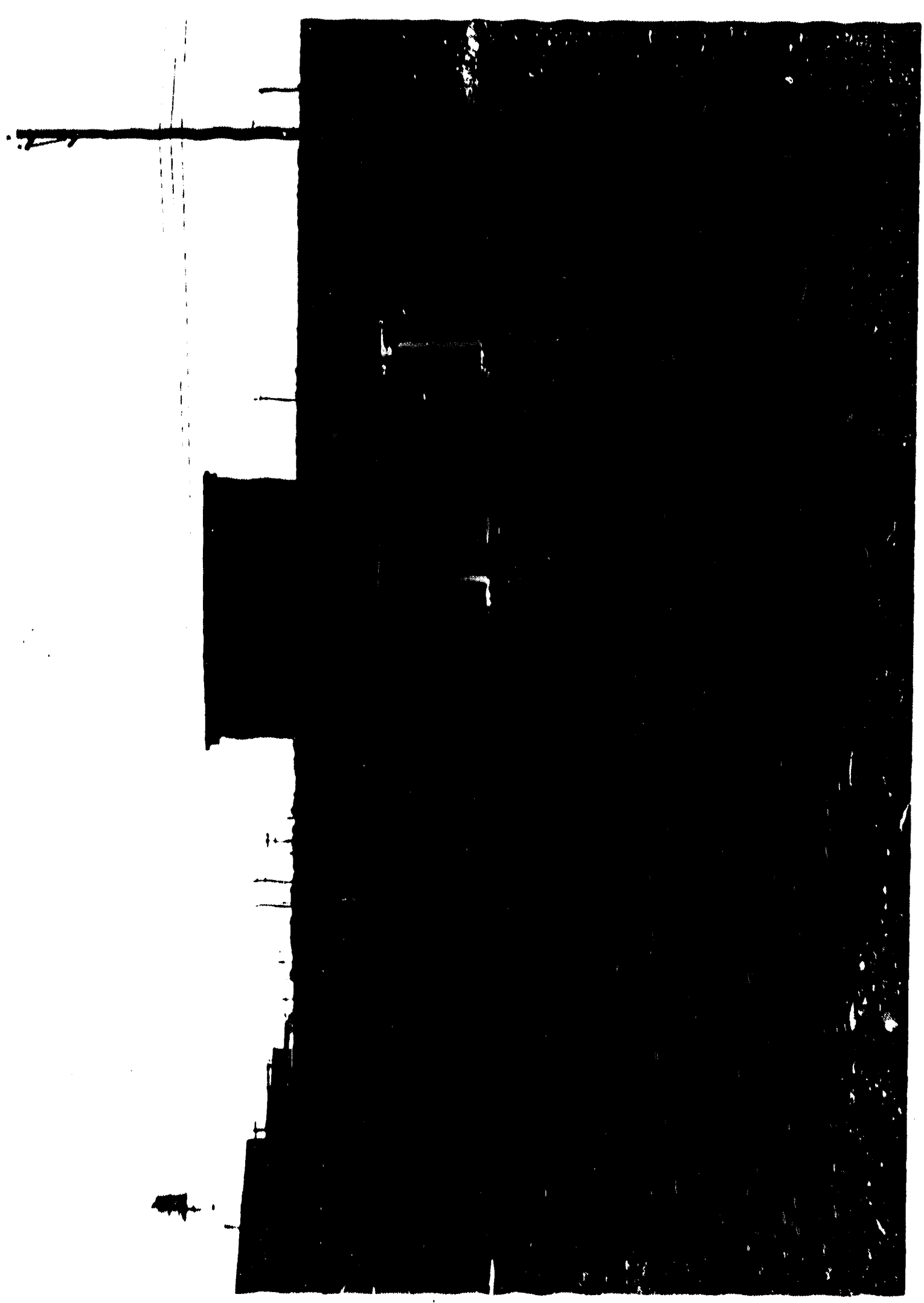

A-5 
Figure A-6. 216-B-9TF Crib and Tile Field.
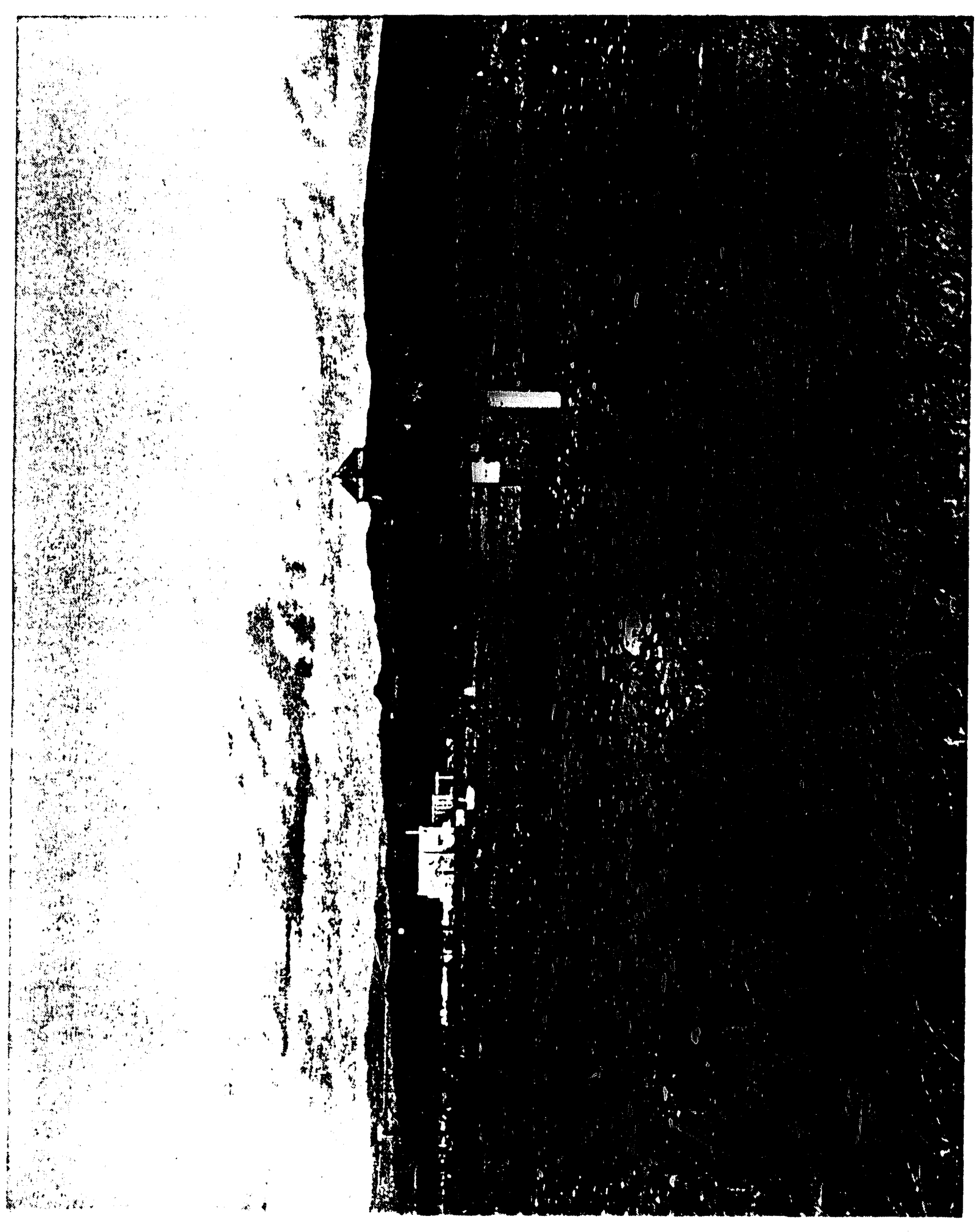
WHC-MR-0270

\section{APPENDIX B}

WASTE SITE SUMMARIES FROM THE

WASTE INFORMATION DATABASE SYSTEM (WIDS) 
Waste Information Data System

General Summary Report

June 3, 1991

SITE NAME: 216-B-5 [309]

ALIASES:

241-B-361 Reverse We11, 241-B-361 Dry Well (309); 241-B-5 Dry Well [2]

SITE TYPE: Reverse Weil (309)

This unit is a registered underground injection well (324)

WASTE CATEGORY: TRU-Contaminated So il Site/Mixed (303)

WASTE TYPE: Liquid [309]

STATUS: Inactive (309) Pre-1980 (309]

START DATE: April 1945 (309)

END DATE: $\quad$ October 1947 (309)

OPERABLE UNIT: 200-BP-5 [329]

REG. AUTHORITY: CERCLA Past Practice (323)

DOE/RL PROGRAM: Radiation Areas Reduction (358)

This site is included in the Tri-Party Agreement Action Plan (329)

PNL Hazardous Ranking System Migration Score: 60.40 (309]

DESIGNATED AREA: 200 East, B Plant. [309]

COORDINATES: N43480 W52855 (center) [309]

LOCATION:

$1,000 \mathrm{ft}$ northeast of 221-B Plant, along Baltimore Avenue (58)

WASTE VOLUME RECEIVED: $30,600,000.00$ liters (309)

CONTAMINATED SOIL VOLUME: $\quad 160.00$ cubic meters (253)

OVERBURDEN SOIL VOLUME: $\quad 560.00$ cubic meters (253)

GROUND ELEVATION: 683.00 feet above MSL (309)

WATER TABLE DEPTH: 283.00 feet below grade [309]

SITE DIMENSIONS (Bottom) (309): Depth: 302.00 feet (309]

Diameter: $\quad .67$ feet [309]

SITE DESCRIPTION:

The unit is $302 \mathrm{ft}$ long, composed of vertical piping with various sizes

in section: 16-in. piping from ground level to $13 \mathrm{ft} ; 12-i n$. piping

placed inside $16-i n$. sections, extending to $100 \mathrm{ft} ; 10-i n$. piping placed

inside 12 -in. sections, extending to $242 \mathrm{ft} ; 8$-in. piping placed inside

10 -in. sections, extending to $302 \mathrm{ft}$ below grade. The lowest $50-\mathrm{ft}$

section of the 8 -in. pipe is perforated [309].

ASSOCIATED STRUCTURES:

A 2-in. stainless steel inlet pipe entering $12 \mathrm{ft}$ below grade [NR]. 


\section{WASTE TYPES AND AMOUNTS:}

Until 9/46, the site received supernatant overflow from 241-B-361

Settling Tank waste via Tank 5-6 in 221-B Building and 1iquid waste from 224-B Building. From $9 / 46$ to $10 / 47$, the site received the cell drainage and other 1 iquid waste via Tank 5-6 in 221-B. The 224-B effluent was rerouted to the new 216-B-7A cribs [309]. The waste was low salt and neutral/basic [58].

\section{COMMENTS:}

The site was deactivated by blanking the pipeline inlet to the well when the radionuclide capacity was reached. Termination was due to groundwater contamination. Of the total activity reported for this site, a certain amount may be retained in the 241-B-361 Settling Tank [58].

\section{SURVEILLANCE INFORMATION 16731}

SURVEILLANCE DATE: $4 / 90$

SURVEY SCHEDULE: AnnUal

SITE POSTING: $\quad$ Surface Contamination

RESULTS/STATUS: General contamination 1,500 to 3,000 dis/min in the northeast corner of the zone. Two areas outside the zone perimter are reported contaminated $15,000 \mathrm{dis} / \mathrm{min} ;$ and 4,000 dis/min. This is an increase from the 1989 survey.

ACTION REQUIRED: Remove contamination from outside the perimeter.

These results show the unit to be out of compliance with the Environmental Compliance Manual. 


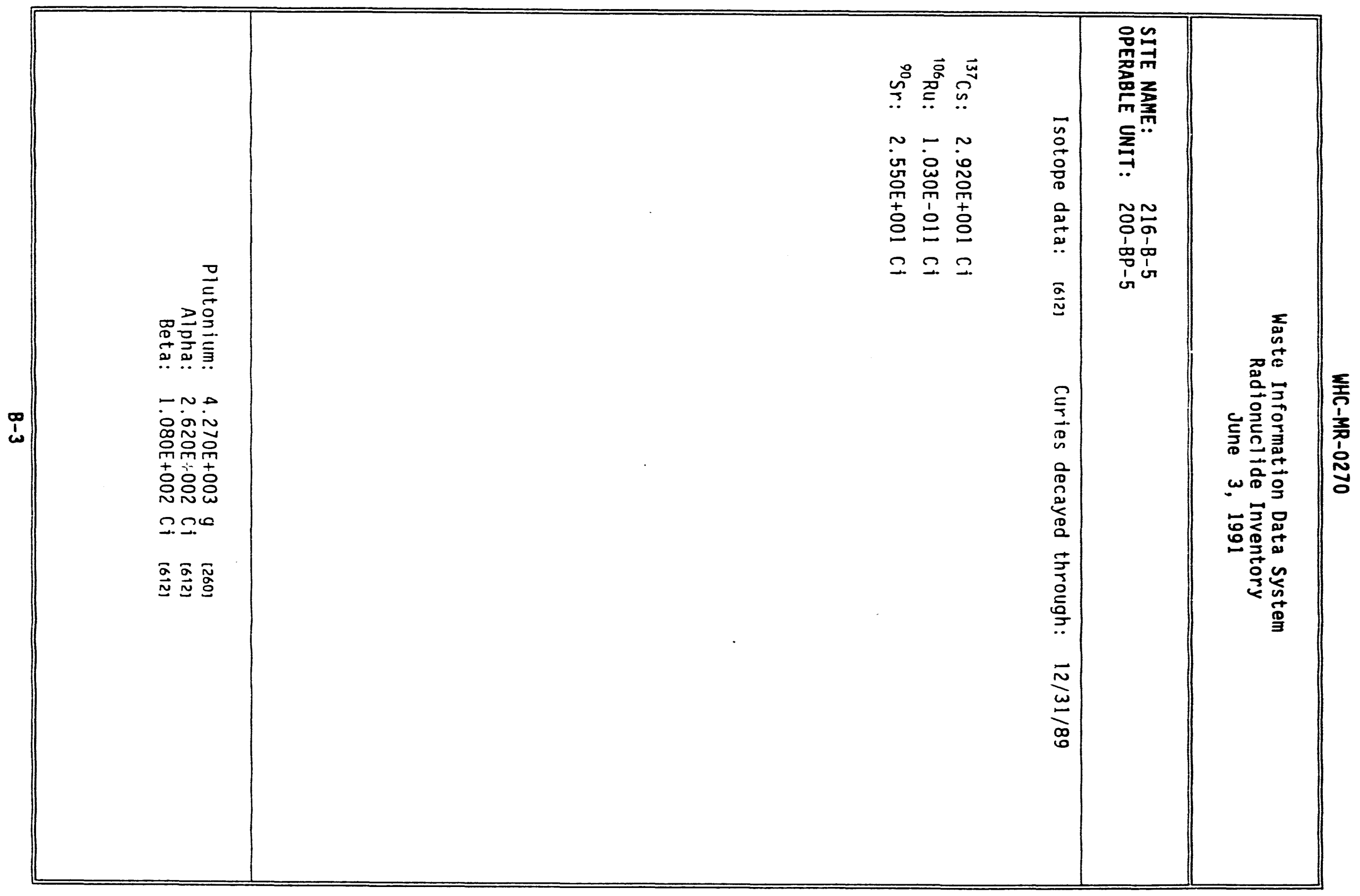


$6 / 03 / 91$

Waste Information Data System

Hazardous Chemical Inventory

(In Kilograms)

Site Name: $\quad 216-B-5$

Operable Unit: 200-BP-5

Bibliography: [315]

INORGANICS

Aluminum Nitrate:

Aluminum Fluoronitrate:

Ammonium Carbonate:

Ammonium Nitrate:

Beryllium:

Calcium Nitrate:

Cadmium (II):

Chromium (VI):

Copper (II):

Copper Sulfate:

Ferric Nitrate:

Ferrocyanide:

Flouride:

Lead (II):

Magnesium Nitrate:

Mercury:

Nickel (II):

Nitrate:
5000.00000

Nitrite:

Nitric Acid:

Oxalate:

12000.00000

Phosphate:

Potassium:

29000.00000

Potassium Borate:

Silver (I):

Sodium:

Sodium Aluminate:

Sodium Dichromate:

Sodium Hydroxide:

Sodium Oxalate:

50000.00000

Sodium Silicate:

Sodium Sulfamate:

Sulfamic Acid:

Sulfate:

Sulfuric Acid:

3300.00000

400000.00000
Uranium

Zinc (II):

\section{CCL4:}

DBP:

Hexone:
MIBK:

TBP:

Trichloroethylene: 


\section{Waste Information Data System \\ General Summary Report \\ June 3, 1991}

SITE NAME: $241-B-361$ [359]

ALIASES:

241-B-361 Settling Tank [315]

SITE TYPE: Settling Tank [315]

WASTE CATEGORY: TRU-Contaminated Soil Site/Mixed [303]

WASTE TYPE: Liquid (315)

STATUS: $\quad$ Inactive (627) Pre-1980 [315]

START DATE: April 1945 [226]

END DATE: $\quad$ September 1947 [226]

OPERABLE UNIT: 200-BP-5 [NR]

REG. AUTHORITY: CERCLA Past Pract ice (323)

DOE/RL PROGRAM: Surplus Facilities Management Program (GF dollars) (358)

This site is included in the Tri-Party Agreement Action Plan [NR]

DESIGNATED AREA: 200 East, B Plant [315]

COORDINATES: $\quad$ N43400 W52890 3370 ]

LOCATION: Northeast of the 221-B Building (315)

SITE DIMENSIONS: Length: 19.00 feet [315]

Diameter: 20.00 feet [315]

SITE DESCRIPTION:

The unit is constructed of 6 -in. reinforced, prestressed concrete. The top of the unit is $6 \mathrm{ft}$ below grade [315]. Eleven risers are visible above grade. One is equipped with a manual tape, a second contains two dip tubes, a third vents the unit, and the eight remaining are blanked off [226].

\section{WASTE TYPES AND AMOUNTS:}

The unit received low salt, alkaline radioactive liquid wastes from cell washings collected in the 5-6W Cell in 221-B and from the 224-B

Building [226]. The unit is now estimated to contain $32,000 \mathrm{gal}$ of sludge $(2.46 \mathrm{~kg}$ of plutonium; $1,060 \mathrm{Ci}$ beta/gamma) [315]. The tank solids present are primarily bismuth phosphate [226].

ENVIRONMENTAL MONITORING:

Routine radiation survey, airborne radionuclide monitoring, and visual inspections are performed [315]. 


\section{RELEASE POTENTIAL:}

Prioritization of this factlity for decommissioning classifies the

relative radiological hazard as high in comparison with other 200 Area surplus facilities [315].

\section{CLEANUP ACTIONS:}

This unit was interim stabilized in 1985 [627]. 


\section{Waste Information Data System \\ General Summary Report \\ June 3, 1991}

SITE NAME: 216-B-9TF (366)

ALIASES:

241-B-361 Crib, 216-B-361 Crib (309)

SITE TYPE: $\quad$ Crib 1309 )

WASTE CATEGORY: Mixed Waste (309)

WASTE TYPE: Liquid (309)

STATUS: Inactive (309) Pre-1980 (309)

START DATE: August 1948 (309)

END DATE: July 1951 (309)

OPERABLE UNIT: 200-BP-5 (329)

REG. AUTHORITY: CERCLA Past Pract ice (323)

DOE/RL PROGRAM: Radiation Areas Reduction (358)

This site is included in the Tri-Party Agreement Action Plan (329)

PNL Hazardous Ranking System Migration Score: 1.03 (309]

DESIGNATED AREA: 200 East, B Plant. (309)

COORDINATES:

N43757 W52617 (crib), N43764 W52575, N43764 W52660, N43951 W52660 (309)

LOCATION:

$1,250 \mathrm{ft}$ south of 241-B Tank Farm, along Baltimore Avenue [581

WASTE VOLUME RECEIVED: $36,000,000,00$ liters (309)

CONTAMINATED SOIL VOLUME: $\quad 1,600.00$ cubic meters (253)

OVERBURDEN SOIL VOLUME: $\quad 6,500.00$ cubic meters (253)

GROUND ELEVATION: 678.00 reet above MSL (309)

WATER TABLE DEPTH: 275.00 feet below grade (309)

SITE DIMENSIONS: Length: 194.00 feet (309)

Width: $\quad 64.00$ feet $[309$ )

Depth: $\quad 30.00$ feet 13091

\section{SITE DESCRIPTION:}

The unit is a wooden structure, 14 by $14 \mathrm{ft}$ (bottom surface) [58] by 8

$\mathrm{ft}$ high, located in an excavation. The timbers are $6 \mathrm{in}$. by $6 \mathrm{in}$. The

tile field, $180 \mathrm{ft}$ by $84 \mathrm{ft}$, is 540 linear $\mathrm{ft}$ of $6-\mathrm{in}$. clay tile pipe,

with each leg in a trench $4 \mathrm{ft}$ wide at the bottom. Pipes are buried

$12 \mathrm{ft}$ deep at head and $6 \mathrm{ft}$ at end. Above and below the pipes are

18 in. of gravel. Roofing felt covers the top side of the pipes. Three

legs branch from each side of clay pipe, leaving at 45 degrees to the

trunk. The side slope is 1:1.5 [309]. 


\section{ASSOCIATED STRUCTURES:}

A $1-f t$ by $1-f t$ by $1 / 2-i n$. steel plate in the center of the top, used to support the vent pipe;

A 4-in. steel pipe, $12 \mathrm{ft}$ long, rising from the top of the structure to

$1.5 \mathrm{ft}$ above grade;

A 6-ft-tall vent above ground connected to $4-i n$. steel pipe [39];

A 2 -in. inlet plpe $\sim 10.5 \mathrm{ft}$ below grade [NR].

\section{WASTE TYPES AND AMOUNTS:}

The site received cell drainage and other 1iquid waste via Tank 5-6 in 221-B Butlding. The waste is low salt, neutral/basic, and contains TRU and fission products [309].

\section{COMMENTS:}

Deactivated by removal of jumper in 241-B-154 Diversion Box when the unit reached its radionuclide capacity [58].

\section{SURVEILLANCE INFORMATION (673)}

SURVEILLANCE DATE: $4 / 90$

SURVEY SCHEDULE: AnnUal

SITE POSTING: Surface Contamination

CAVE-IN POTENTIAL: There is a cave-in potential at the south end.

RESULTS/STATUS: Several areas of contamination up to $60,000 \mathrm{dis} / \mathrm{min}$. Similar contamination reported in 1989.

ACTION REQUIRED: Continue to monitor for change.

These results show the unit to be out of compliance with the Environmental Compliance Manual. 


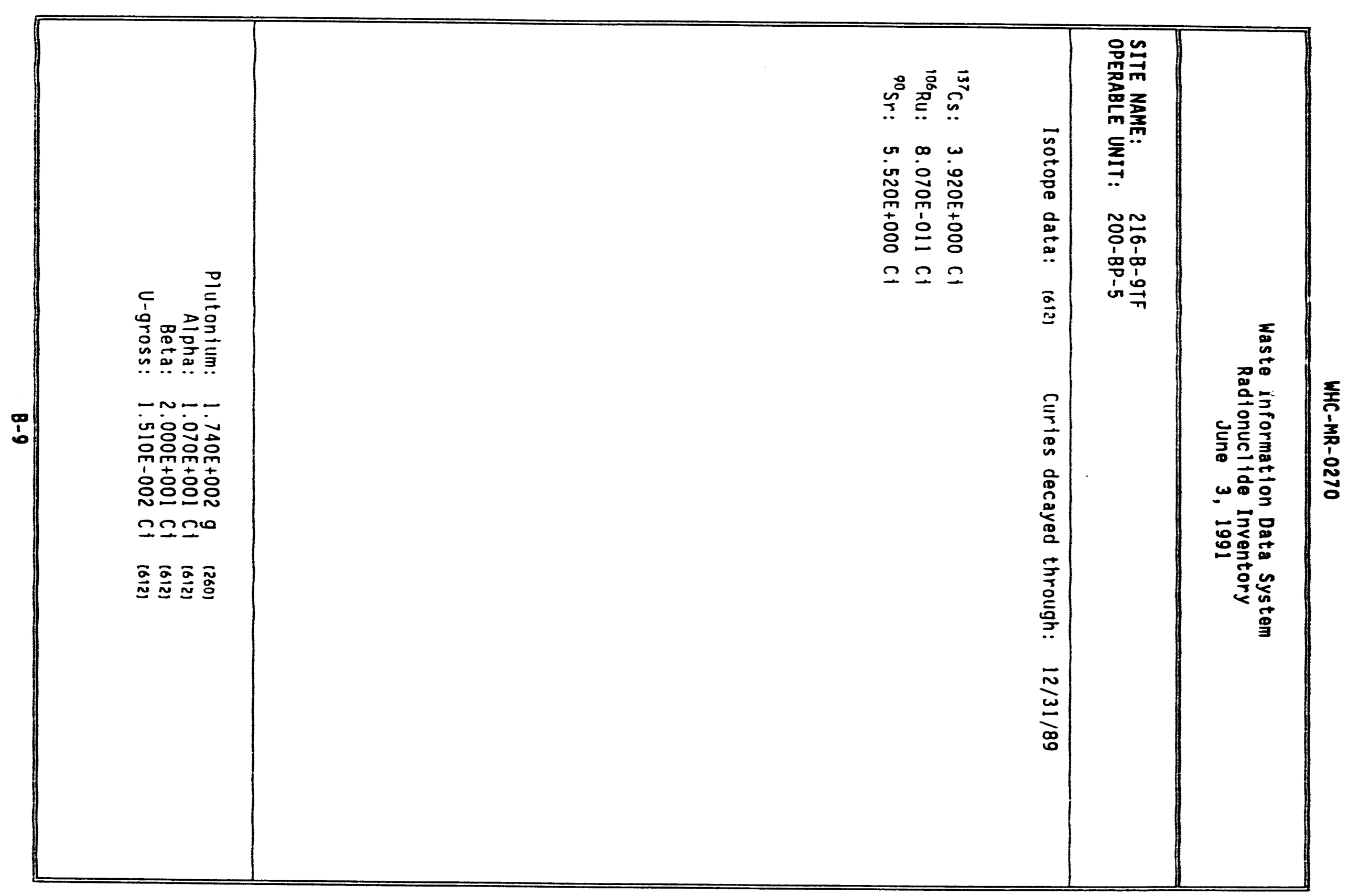


$6 / 03 / 91$

Waste Information Data System

Hazardous Chemical Inventory

(In Killograms)

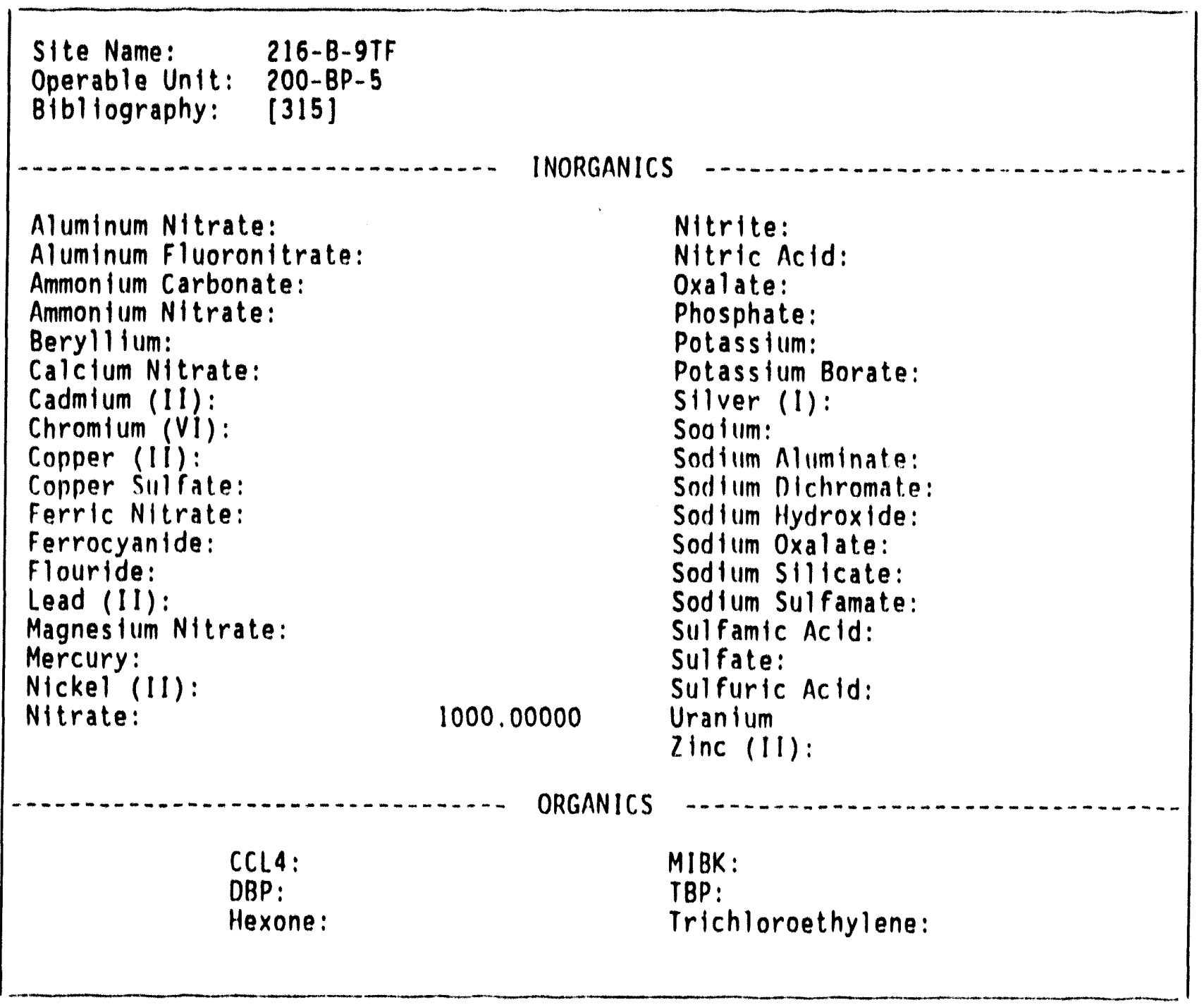




\section{Waste Information Data System \\ General Summary Report \\ June 3, 1991}

SITE NAME: $216-B-56$ (58)

SITE TYPE: Crib 1581

WASTE CATEGORY: NOIhazardous/Nonradioactive (NR)

WASTE TYPE: Llquid (58)

STATUS: Inactive (58) Never Used (58)

OPERABLE UNIT: $200-B P-5$ (329)

REG. AUTHORITY: CERCIA Past Practice 1323)

This site is included in the Tri-Party Agreement Action Plan (329)

DESIGNATED AREA: 200 East, B Plant (58)

COORDINATES: N42885 W52600, N42955 W52600 (58)

LOCATION:

$\sim 1,000 \mathrm{ft}$ northeast of $221-\mathrm{B}$ Bullding and $-400 \mathrm{ft}$ north of 7 th Street

(58)

GROUNO ELEVATION: 692.00 feet above MSL 1581

WATER TABLE DEPTH: 188.00 feet below grade (NR)

SITE DIMENSIONS (Bottom) (58): Site Area: 700.00 square feet (58)

Length: $\quad \quad \quad 70.00$ feet (2)

Width: $\quad 10.00$ feet 121

SITE DESCRIPTION:

Gravel fllled [58]. Pipeline to the unit is not installed [2].

WASTE TYPES AND AMOUNTS:

Future use: to receive organtc waste from 221-B Building [58].

SURVEILLANCE INFORMATION (673)

SURVEILLANCE DATE: $\quad 4 / 90$

SURVEY SCHEDULE: AnnUal

SITE POSTING: Underground Radioactive Material

RESULTS/STATUS: No contamination detected. No change since survey of $10 / 88$.

These results show the unit to be in compliance with the Environmental Compliance Manual. 


\section{Waste Information Data System \\ General Summary Report \\ June 3, 1991}

SITE NAME: $216-B-59$ (315)

ALIASES:

216-B-58 Trench, 216-B 58 Ditch (58); 216-B-59 Retention Basin (315);

216-B-59B (359)

SITE TYPE: Retention Bas in (137)

WASTE CATEGORY: Mixed Waste (NR)

WASTE TYPE: Liquid (315)

STATUS: Active (315)

START DATE: $\quad$ December 1967 (58)

OPERABLE UNIT: 200-BP-5 (329)

REG. AUTHORITY: CERCLA Past Practice (323)

DOE/RL PROGRAM: Radiation Areas Reduction (358)

This site is included in the Tri-Party Agreement Action Plan (329)

DESIGNATED AREA: 200 East, B Plant 13151

COORDINATES: $\quad$ N43001 W52787, N43284 W52504 (center line) [58]

LOCATION: $\quad \sim 700 \mathrm{ft}$ northeast of the 221-B Building (58)

WASTE VOLUME RECEIVED: $\quad 477,000.00$ 1iters (612)

CONTAMINATED SOIL VOLUME: $\quad 250.00$ cubic meters (330)

OVERBURDEN SOIL VOLUME: $\quad 2,900.00$ cublc meters $(330)$

GROUND ELEVATION: 685.00 feet above MSL [402]

WATER TABLE DEPTH: 285.00 feet below grade (NR)

SITE DIMENSIONS (Bottom) (402): Length: 400.00 feet (402)

Width: $\quad 20.00$ feet (402)

Depth: $\quad 12.00$ feet 14021

SITE DESCRIPTION:

A 15-in. inlet pipe enters the southwest end of the unit $4 \mathrm{ft}$ above the bottom surface. The unit is concrete-lined and compartmented into 3 sections and covered for retention of radioactive water over prescribed limits [402]. 
ASSOCIATED STRUCTURES:

Cover floats, $20 \mathrm{ft}$ long, 7 each sectior, running the width of the unit, 6 each section running lengthwise, placed end to end along centerline, $-11 \mathrm{ft}$ each;

12-in.-radius half-pipe section placed along one side, $5 \mathrm{ft}$ above the bottom, $\sim 13 \mathrm{ft}$ long;

4-in. concrete slab, $4 \mathrm{ft}$ wide, placed along the side slope under pipe section and $4 \mathrm{ft}$ along bottom, $\sim 68 \mathrm{sq} \mathrm{ft}$;

Cover placed over surface area, $5 \mathrm{ft}$ above bottom, $\sim 8,900 \mathrm{sq} \mathrm{ft}$;

Liner material placed over 1 iner along one side, $6 \mathrm{ft}$ above bottom, running to $6 \mathrm{ft}$ along bottom, $204 \mathrm{sq} \mathrm{ft}$. Liner placed along sides and bottom from $6 \mathrm{ft}$ above bottom, $\sim 21,500 \mathrm{sq} \mathrm{ft}$;

Sump structure, $2 \mathrm{ft} 8 \mathrm{in}$. by $36 \mathrm{in.}$, placed below bottom of the unit [402].

\section{WASTE TYPES AND AMOUNTS:}

The unit has received diverted cooling water from the 221-B

Building. Only one diversion occurred $(3 / 68)$ before the unit was

lined. The unit still receives diverted wastes only. Then they are pumped back into the building and processed [137].

\section{COMMENTS:}

The liner was installed between 1974 and 1975. The unit is now used as a retention basin [137].

\section{SURVEILLANCE INFORMATION (473)}

SURVEILLANCE DATE: $10 / 89$

SURVEY SCHEDULE: AnnUal

SITE POSTING: Surface Contamination

CAVE-IN POTENTIAL: None

RESULTS/STATUS: No contamination detected. No change since survey of $10 / 88$.

ACTION REQUIRED: No action required.

These results show the unit to be in compliance with the Environmental Compliance Manual. 
Waste Information Data System

Radionuclide Inventory

June 3,1991

\section{SITE NAME: $\quad 216-B-59$}

OPERABLE UNIT: 200-BP-5

Isotope data: [612]

Curies decayed through: 12/31/89

${ }^{137} \mathrm{Cs}: \quad 1.200 \mathrm{E}-002 \mathrm{Ci}$

${ }^{90} \mathrm{Sr}: \quad 2.890 \mathrm{E}-002 \mathrm{Ci}$

Beta: $8.320 \mathrm{E}-002 \mathrm{Ci}$ [612] 


\section{Waste Information Data System \\ General Summary Report \\ June 3, 1991}

SITE NAME: 241-B-154 [359]

ALIASES:

241-B-154 Diversion Box (315)

SITE TYPE: $\quad$ Diversion BoX (315)

WASTE CATEGORY: Mixed Waste (315)

WASTE TYPE: Liquid [315]

STATUS: $\quad$ Inactive (315) Post-1980 (315)

START DATE: $\quad 1945$ (315)

END DATE: June 1984 (315)

OPERABLE UNIT: $\quad 200-B P-5$ [329]

TSD NUMBER: $\quad S-2-4$ [606]

REG. AUTHORITY: CERCLA Past Practice (323)

DOE/RL PROGRAM: Stabilization and Isolation (358)

This site is included in the Tri-Party Agreement Action Plan 1329

DESIGNATED AREA: 200 East, B Plant [58]

COORDINATES: $\quad$ N42543 W52758 (58)

LOCATION: $\quad \sim 206 \mathrm{ft}$ east of Baltimore Avenue [NR], east of 221-B [58]

GROUND ELEVATION: 697.00 feet above MSL [403]

WATER TABLE DEPTH: 294.00 feet below grade [NR]

SITE DIMENSIONS: Length: 36.00 feet 158 )

Width: $\quad 9.00$ feet $(58)$

Depth: $\quad 17.00$ feet 14031

SITE DESCRIPTION:

The unit is a reinforced concrete structure with 2 -ft-thick walls. There are 24 nozzles (3" Hanford style) housed in this unit [403].

ASSOCIATED STRUCTURES:

Associated with 241-B-302-B Catch Tank and 241-B Tank Farm [315].

Interconnects 241-B-151, 241-B-152, and the 221-B Building [58].

WASTE TYPES AND AMOUNTS:

This unit was used for transfer of waste solutions from processing and and decontamination operations. Volumes were variable according to specific plant operation [315]. Contamination is estimated to be high in alpha, beta, and gamma [58].

KNOWN RELEASES:

UPR-200-E-77 [309]. 
ENVIRONMENTAL MONITORING:

Leak detection and air monitoring are performed continuously with in the tank farm in which this unit is located [315].

RELEASE POTENTIAL:

Diversion boxes and receiving vaults drain to catch tanks or to single-shell tanks. This unit has been isolated and weather covered. It is designed to contain leaks from transfers and drainage from operations within the unit. Multiple transfer pipelines remain in place between the unit and processing plants and storage tank [315]. 
WHC-MR-0270

\section{Waste Information Data System \\ General Summary Report \\ June 3,1991}

SITE NAME: $241-B-302 B$ [359]

ALIASES:

241-B-302-B Catch Tank [315]

$\begin{array}{ll}\text { SITE TYPE: } & \text { Catch Tank } 1627) \\ \text { WASTE CATEGORY: } & \text { Mixed Waste [315] } \\ \text { WASTE TYPE: } & \text { Liquid (315) } \\ \text { STATUS: } & \text { Inactive (627) Post-1980 (315) } \\ \text { START DATE: } & 1945(315) \\ \text { END DATE: } & \text { July } 1985 \text { (315) }\end{array}$

OPERABLE UNIT: $200-B P-5$ [329]

REG. AUTHORITY: CERCLA Past Practice (323)

DOE/RL PROGRAM: Stabilization and I solation [358]

This site is included in the Tri-Party Agreement Action P1an 1329

DESIGNATED AREA: 200 East, B Plant [315]

COORDINATES: $\quad$ N42600 W52758 (329)

LOCATION:

The 241-B Tank Farm is $\sim 3,000 \mathrm{ft}$ northeast of the 221-B Building, north of 10 th St. and adjacent to Baltimore Ave. [534]

ASSOCIATED STRUCTURES:

Associated with 241-B Tank Farm and 241-B-154 Diversion Box [627].

WASTE TYPES AND AMOUNTS:

This unit was used for transfer of waste solutions from processing and decontamination operations. Volumes were variable according to specific plant operation [315].

ENVIRONMENTAL MONITORING:

Leak detection and air monitoring are performed continuously within the

tank farm in which this unit is located [315].

\section{CLEANUP ACTIONS:}

This unit was isolated in 1985 [627]. 


\section{Waste Information Data System \\ General Summary Report \\ June 3,1991}

SITE NAME: UN-200-E-7 (360)

ALIASES:

UPR-200-E-7 [309]

SITE TYPE: Unplanned Release (309)

WASTE CATEGORY: Mixed Waste [NR]

WASTE TYPE: Liquid [309]

STATUS: Inactive (309) Post-1980 (309]

OCCURRENCE DATE: November 30, 1954 (309]

OPERABLE UNIT: 200-BP-5 (329]

REG. AUTHORITY: CERCLA Past Practice [323]

DOE/RL PROGRAM: Environmental Restoration (358)

This site is included in the Tri-Party Agreement Action Plan [329]

PNL Hazardous Ranking System Migration Score: 1.45 (309]

DESIGNATED AREA: 200 East Area (309)

COORDINATES: $\quad$ N43757 W52617 (309)

LOCATION: $\quad$ A region near the 216-B-9 Crib and Tile Field (309)

WASTE VOLUME RECEIVED: $18,927.00$ 1iters (309)

GROUND ELEVATION: 678.00 feet above MSL [309]

WATER TABLE DEPTH: 275.00 feet below grade [309]

SITE DIMENSIONS (Top) 13091: Length: 30.00 feet 1309 ]

Width: $\quad 30.00$ feet $[309$ ]

WASTE TYPES AND AMOUNTS:

The release consisted of cell wash water. The maximum dose rate was

$1.7 \mathrm{R} / \mathrm{h}$ [309].

KNOWN RELEASES:

A leak in the waste 1 ine from the 221-B Building to 241-B-361 [309]

CLEANUP ACTIONS:

The contamination was covered, and the area was posted as "Underground Contamination" [309]. 


\section{Waste Information Data System \\ General Summary Report \\ June 3, 1991}

SITE NAME: UN-200-E-45 [360]

ALIASES:

UPR-200-E-45 (309)

\section{SITE TYPE: Unplanned Release [309] \\ WASTE CATEGORY: Mixed Waste (NR) \\ WASTE TYPE: Liquid [309]}

STATUS: Inactive (309) Pre-1980 (309]

OCCURRENCE DATE: August 26, 1974 (309)

OPERABLE UNIT: $200-B P-5$ (329)

REG. AUTHORITY: CERCLA Past Practice (323)

DOE/RL PROGRAM: Stabilization and Isolation (358)

This site is included in the Tri-Party Agreement Action Plan [329]

PNL Hazardous Ranking System Migration Score: 1.14 (309]

DESIGNATED AREA: 200 East Area (309)

COORDINATES: $\quad$ N42529 W52725 (370)

LOCATION:

An area running in a southeasterly direction from the 241-B-154

Diversion Box [309]

SITE DIMENSIONS (TOp) (309): Site Area: 30,000.00 square feet [309]

Length: $\quad 300.00$ feet (309)

Width: $\quad 100.00$ feet 13091

\section{WASTE TYPES AND AMOUNTS:}

Unknown beta/gamma with readings up to $50,000 \mathrm{ct} / \mathrm{min}$ [309].

KNOWN RELEASES:

A cleanup operation at the 241-B-154 Diversion Box inadvertently

contaminated an area in the immediate vicinity [309].

\section{CLEANUP ACTIONS:}

The contaminated roadway was washed off with water, and the borrow pit slopes were bladed. The contaminated soil was collected and placed in a burial trench [309]. 


\section{Waste Information Data System \\ General Summary Report \\ June 3, 1991}

SITE NAME: UPR-200-E-77 (309)

ALIASES:

UN-216-E-5, 241-B-154 Diversion Box Ground Contamination (58)

SITE TYPE: Unpianned Release (309)

WASTE CATEGORY: Mixed Waste (NR)

WASTE TYPE: Liquid (309)

STATUS: Inactive (309] Pre-1980 (309)

OCCURRENCE DATE: 1946 [309]

OPERABLE UNIT: $200-B P-5$ (329)

REG. AUTHORITY: CERCLA Past Practice (368)

This site is not included in the Tri-Party Agreement Action P1an (329)

PNL Hazardous Ranking System Migration Score: 1.09 [309]

DESIGNATED AREA: 200 East Area (309)

COORDINATES: $\quad$ N42550 W52800 (309)

LOCATION:

Near the 241-B-154 Diversion Box, east of 221-B Building, near the corner of Baltimore and Seventh (58)

GROUND ELEVATION: 625.00 feet above MSL [309]

WATER TABLE DEPTH: 233.00 feet below grade (309)

WASTE TYPES AND AMOUNTS:

Metal waste solution from 221-B with fission products measuring $\sim 1$

$C i$. A radiological survey on $10 / 75$ measured surface contamination to

$80,000 \mathrm{ct} / \mathrm{min}[309]$.

KNOWN RELEASES:

Metal waste solution contaminated the ground around the 241-B-154

Diversion Box as a result of work associated with a leaky jumper in the box [97].

COMMENTS:

The site was stabilized, but recontamination has occurred [NR].

CLEANUP ACTIONS:

The contamination was covered with $1 \mathrm{ft}$ of clean soil [97]. 


\section{SURVEILLANCE INFORMATION (474)}

SURVEILLANCE DATE: $9 / 89$

SURVEY SCHEDULE: AnnUal

SITE POSTING:

Surface Contamination

RESULTS/STATUS: Area of contamination up to $3.5 \mathrm{mR} / \mathrm{h}$ NE of zone. Increased readings since survey of $9 / 88$.

ACTION REQUIRED: Issued SCIR to require clean-up and identify contamination zone.

These results show the unit to be out of compliance with the Environmental Compliance Manual. 

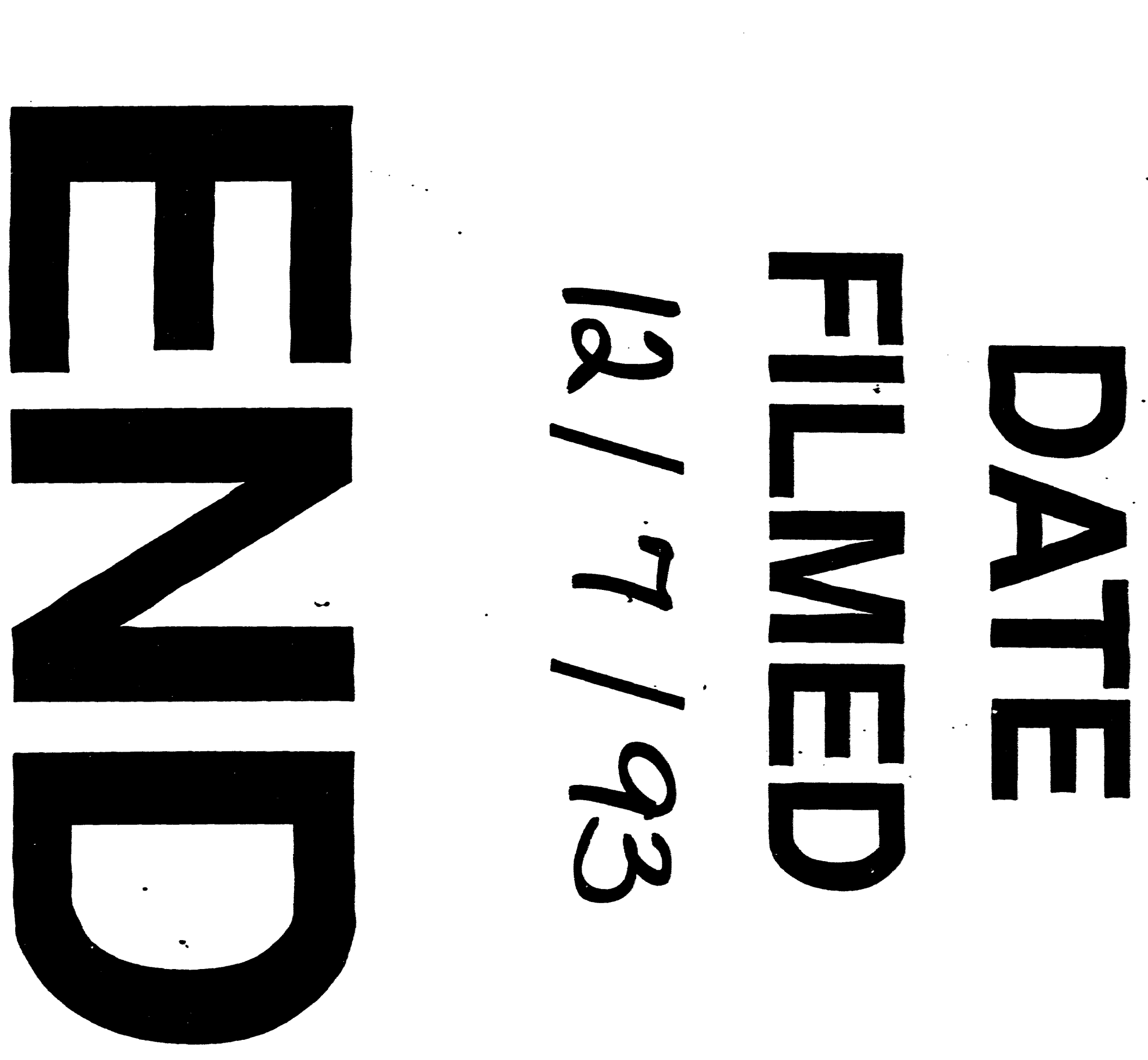


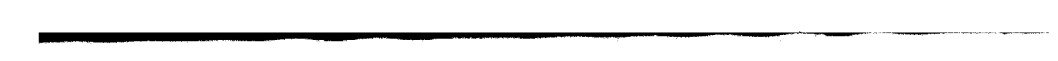

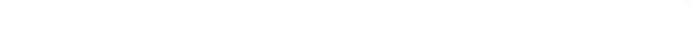

